\title{
The Impact of the Introduction of Uniform European Collective Action Clauses on European Government Bonds as a Regulatory Result of the European Sovereign Debt Crisis
}

\author{
Nicoletta Layher ${ }^{1}$ (D) and Eyden Samunderu ${ }^{2, *}$ \\ 1 Technik Museum Sinsheim Speyer, Eberhard-Layher Str. 2, 74889 Sinsheim, Germany; \\ nlayher@technik-museum.de \\ 2 Department of Strategic Management, International School of Management (ISM), Otto Hahn-Str. 19, \\ 44227 Dortmund, Germany \\ * Correspondence: eyden.samunderu@ism.de; Tel.: +49-231-97513968
}

Citation: Layher, N.; Samunderu, E. The Impact of the Introduction of Uniform European Collective Action Clauses on European Government Bonds as a Regulatory Result of the European Sovereign Debt Crisis. J. Risk Financial Manag. 2021, 14, 1. https://dx.doi.org/10.3390/ jrfm14010001

Received: 14 October 2020 Accepted: 14 December 2020 Published: 22 December 2020

Publisher's Note: MDPI stays neutral with regard to jurisdictional claims in published maps and institutional affiliations.

Copyright: (c) 2020 by the authors. Licensee MDPI, Basel, Switzerland. This article is an open access article distributed under the terms and conditions of the Creative Commons Attribution (CC BY) license (https: / / creativecommons.org/ licenses/by/4.0/).

\begin{abstract}
This paper conducts an empirical study on the inclusion of uniform European Collective Action Clauses (CACs) in sovereign bond contracts issued from member states of the European Union, introduced as a regulatory result of the European sovereign debt crisis. The study focuses on the reaction of sovereign bond yields from European Union member states with the inclusion of the new regulation in the European Union. A two-stage least squares regression analysis is adopted in order to determine the extent of impact effects of CACs on member states sovereign bond yields. Evidence is found that CACs in the European Union are priced on financial markets and that sovereign bond yields do respond to the inclusion of uniform CACs in the European Union.
\end{abstract}

Keywords: collective action clauses; sovereign debt; bond yields

\section{Introduction}

Since the formation of the European Union in the 20th century and the launching of the Euro in January 1999 as a single currency for the 19 of the 28 member states of the European Union (Europa.eu 2015) up to date, the European Union has faced significant level of challenges and complexities. These challenges included surging member states debt, rapidly rising bond yield spreads, and a collapse of financial institutions, which subsequently dragged Europe's economies into sovereign debt. As a counter measure to mitigate the economic collapse of member states, the Collective Action Clauses (CACs) were adopted as a cushion measure in Europe.

In order to elucidate the backdrop that culminated in Europe's sovereign debt crisis, one has to briefly observe from how the subprime crisis in the United States (US) had a contagion effect to the European economies. CACs are the result of the financial crises that arose some years in advance of the introduction of uniform CACs in Europe. The subprime mortgage crisis, which resulted from a real estate "bubble" in the United States, laid the grounds for the European sovereign debt crisis. Wali Ullah and Ahmed (2014) argue that the European sovereign debt crisis is a combination of "international trade imbalances, impact of the global financial crisis 2007-2012, failure in bailout approaches of European governments that troubled banking industries and private bondholders and high-risk lending and borrowing policies enforced by unrestricted credit requirements during 2002 to 2008". This subsequently triggered a real estate bubble in Europe and drew the situation closer to a financial meltdown that dragged economies with it, hence, the contagion effect (Bradley and Gulati 2013a). Wali Ullah and Ahmed (2014) further echoed that sovereign defaults generally occur in combination of sovereign debt, banking, and balance of payment (BOP) crisis.

The legal basis for CACs in Europe is Article 12 of the European Single Market (ESM) Treaty. Here it is stated that "Collective Action Clauses shall be included, as of 1 January 
2013, in all new Euro area government securities, with maturity above one year, in a way which ensures that their legal impact is identical" (Art. 12 ESM Treaty). The actual legal text for CACs was developed by the EFC Sub-Committee on Sovereign Debt Markets with representatives from all 27 European Union member states, the European Commission, European Central Bank, European Investment Bank, and the European Financial Stability Facility (Sabel 2013). This was approved by the European Economic and Finance Committee (EFC) on 18 November 2011. CACs are part of the bond terms and conditions. In case of financial instability, they provide rules for majority voting to change the terms and conditions of bonds (Bauer 2013). Since 1 January 2013, those clauses have been introduced as uniform CACs in the European Union. Government bonds issued after January 2013 with a maturity exceeding one year are to contain uniform CACs (Economic and Financial Committee 2015a). Part of such government bonds are all of a government's bills, bonds, debentures, notes, and other debt securities including a range of financial instruments such as fixed and floating rate bonds, unsecured and collaterized bonds, short and long-term instruments, and zero-coupon obligations (Sabel 2013). Regional and municipal bonds, however, are excluded from these rules and may be issued without CACs (Economic and Financial Committee 2015b). Thus, the model of CAC must be included within all the Euro area sovereign domestic and international debt securities with an original stated maturity of more than one year (Sabel 2013).

CACs should reduce the need for bailouts (Weidemaier and Gulati 2013). They help struggling economies to ascertain the possibility to restructure the payment conditions of sovereign debt through majority voting. Adopting this "debt restructuring tool", member states of the European Union intended to introduce an orderly mechanism of restructuring sovereign debt, which will be significant for future crises and prevent future bailouts (Bauer 2013).

The main purpose of the Euro area model CAC is twofold. First, to facilitate the restructuring of an issuer's sovereign debt, through a majority voting of not less than 66.67 percent of all bondholders, which is then binding for every bondholder. It is believed to reduce the so-called hold-out problem (Economic and Financial Committee 2015a), which is also referred to as the problem of non-participating creditors (Buchheit et al. 2013). Second, Bauer (2013) explains, "the inclusion of ( . . ) [Collective Action Clauses] was part of what has come to be known as Private Sector Involvement (PSI)". This means, rescue measures "between sovereign states within the Euro area was conditional on a bundle of measures which should ensure that private investors recognize and bear the risk of their investment decisions" (Bauer 2013). The main purpose of this is to give CACs in Europe a kind of "disciplinary function".

As this fundamental regulation came into force, the question rises whether the newly introduced CACs are already recognized on capital markets, particularly concerning sovereign bond yields. Are yields rising or falling with the introduction of the new regulation? If so, does a relationship exist between a rise or fall in yields and the inclusion of the new regulation? Does this new regulation already have significant and moderating impact among the European Union member states?

The central focus of this study is to shed light on how European CACs have an effect on European sovereign bond yields, as CACs were introduced as a regulatory result of the financial crisis in Europe. There might be some similarities with other crisis on the globe, but the European Union tried to counteract with European CACs. Since January 2013, when the new clause on sovereign bond contracts was launched, investors face a higher risk when buying sovereign bonds as the clause permits with the help of a majority vote to restructure debts (Art. 12 ESM Treaty). Thus, this study focuses on the impact of European CACs on European sovereign bond yields with a maturity of either five or ten years. Moreover, it is analyzed whether a CAC premium is demanded for the higher risk and whether this has a relation with the variables rating and result. Nevertheless, due to the shortly introduced European CACs, literature on the impact on European sovereign bond yields is still relatively sparse. 


\section{Research Aims}

Although there has been considerable research surrounding sovereign bond yields, the aim of this study is to establish a groundwork for the initial steps in examining the impact of the introduction of European CACs on European sovereign bond yields. Previous studies have debated on the topic of using CACs as tools for restructuring by observing their impact on the country's sovereign bond yields. Results have been relatively mixed and ambiguous, with contrasting results due to data accuracy problems (Bardozzetti and Dottori 2014) and even raising concerns regarding endogeneity issues. Hence, how CACs impact sovereign bond yields is essentially an empirical issue. Therefore, in our study we attempt to shed light on the impact of European CACs on European sovereign bond yield behaviour spread by adopting a methodology that test for endogeneity and checking for causality through the instrument variable approach with the two-stage least squares regression analysis. Within the backdrop of numerous and heterogeneous contributions in the field of study of CACs and bond yields, there still exist the enigma of differences among findings relating to this CAC impact. Advocates for CACs that view them as a key instrument designed to facilitate restructuring of repayment terms have argued that adopting such proxy can lower borrowing costs of for both noninvestment-grade and investment grade issuers. Sceptics view CACs from a different angle by arguing that CACs in fact increase the cost of borrowing because investors believe that such clauses make restructuring easier and subsequently compromise future bond returns (Chung and Papaioannou 2020).

\section{Literature Review}

Since the 1990s, there have been a significant number of contributing empirical literature that has attempted to address and elucidate the notion relationship between the adoption of CACs for sovereign bond issues and their yields. However, no consensus has emerged on this causality effect relationship due to the fact that the previous studies done on this topic employed a variety of approaches, methodologies and datasets, resulting in multiple lenses of analysis. Thus, several studies have attempted to explore the cost aspects of CACs, without consistent empirical findings on the market impact of the inclusion of CACs on bond yields (Chung \& Papaioannou). This is because empirical analysis can enhance the determination of bond pricing impact, but not all previous studies have been able to provide clear conclusions, with some findings exhibiting significant levels of data caveats (Bardozzetti and Dottori 2014; Schumacher et al. 2020; Ratha et al. 2018; Stolper and Dougherty 2019; Picarelli Osvaldo et al. 2019). However, Tsatsaronis (1999) conducted the first systematic study on the yield effect of CACs by considering primary data on a variety of international sovereign bonds issued after 1990. Since there was no existing information on CACs at the bond level, the governing law of issuance was instead adopted as a proxy, meaning that "all bond issued under UK governing law were assumed to endowed with collective action clauses, while those issued under US governing law were not" (Bardozzetti and Dottori 2014).

The Eurozone sovereign debt crisis initiated European policy makers to map out the core policy initiative provision called CACs. The primary objectives of the CACs allowed a super-majority of creditors to impose restructuring terms on minority holdout creditors (Bradley and Gulati 2013a). This means that there would then be an efficient resolution process designed to reduce the cost of restructuring.

This policy initiative meant that Eurozone nations had to find measures that were designed to mitigate the need for future financial bailouts after Greece's first bailout in mid2010. In their work, Bradley and Gulati (2013b) explicitly outline the relevance of the holdout problem in the sovereign debt context by identifying three major observations: Firstly, there is no bankruptcy regime for sovereign states whereby there is a bankruptcy type of process which is supervised by the courts of law. The second observation is that when restructuring a sovereign debt, there is the essentiality of engaging a third party from the Official Sector, which may include the following institutions: International Monetary Fund 
(IMF), European Central Bank (ECB), or the US Treasury. The final observation brought into light here underlines the fact that prior to 2003, the standard practice in sovereign bonds that were written under New York law had been designed primarily for bond-holder rights, which meant essentially that this was for individual rather than collective, as seen in the EU. Furthermore, Bradley and Gulati (2013b) extend further comments by amplifying the underpinning arguments of CACs as raised in the debate from Eichengreen (2003) and Portes (2004), who both categorically questioned the underlying costs of restructuring financially troubled sovereign states. The debate weighs in on whether any savings are captured (post-ante restructuring) versus the increased cost of borrowing (ex-ante). Both positive and negative effects are well documented in literature on how CACs impact sovereign bond yields, hence there is no common consensus to amplify the core impact of CACs. As a result, multiple lenses have been used to draw some conclusion on their impact and this debate remains visibly ambiguous (Bradley and Gulati 2013a). In their work, Bradley and Gulati (2013a) argue that CACs positively moderate "the coordination of dispersed investors" resulting in significant reduction of the effectiveness of holdouts, which ultimately makes restructuring effort easier for the sovereign debtors. Contrary to this line of argument, critics like Ghosal and Thampanishvong (2013) and Pitchford and Wright (2010) observe CACs from a negative lens, thus, highlighting the fact that if restructurings are softened, debtor sovereigns may be motivated to engage in excessive borrowing and may exhibit irresponsibility once the debt has been issued. This raises a key critical observation on whether the adoption of CACs as a blanket policy can alleviate economies from spiraling debts.

Existing literature (for example, Gugiatti and Richards 2004; Eichengreen and Mody 2004; Bradley and Gulati 2013b; Antonakakis and Vergos 2013) elaborate how the pricing of CACs differs in the way the analyses are conducted, and the results found through the empirical analyses that are employed to capture their impact. Eichengreen and Mody (2004) show that yields on primary sovereign debt markets (initial auctions) are higher when bonds do have CACs, in particular for low-rated borrowers like Greece or Italy who have battled with the EU to secure financial bailouts. This is of interest, because imposing a restructuring debt of Greece, either via bond swap or extending bond maturities, meant the private holders of Greek bonds would also share the burden. Thus, existing theory provides little guidance on how CACs should affect the pricing of bonds (Becker et al. 2003). Whilst there is a debate on the impact of CACs, there is the propensity that CACs may increase the cost of debt financing due to borrower moral hazard (Dixon and Wall 2000).

However, some models have been able to provide some formal formulations such as that of Dooley (2000). In his work, he proposed a model based on standard assumptions regarding sovereign borrowers, whereby borrowers cannot be forced to repay, and any forms of collateral measures or monitoring arrangements are deemed to be impossible. This raises again the debate on the use of CACs and their impact on pricing of sovereign bond yields. Becker et al. (2003) concluded that their findings did not reveal any evidence to support the notion that through the use of CACs, the borrowing costs for lower-rated issuers is significantly increased. This study meant that the point estimates for the impact of CACs on borrowing costs associated with both high and low issuers are almost always negative unlike Eichengreen and Mody (2004) findings, which showed the effects to be quite small.

In constructing a sample, most of the literature make use of bonds subject to New York law and English law. Since 2003, New York law bonds generally do not contain CACs whereas bonds subject to English law usually contain such clauses. Due to this fact, most literature on CACs impact has been post the 2003 period.

The principal aim here is to draw a sharp comparison on similar bonds which do contain CACs or not, in order to find evidence whether CACs do have an impact on bond yields. Empirical studies (For example, Antonakakis and Vergos 2013) made further attempts to elucidate the contagion effect of sovereign debt within the Eurozone, by observing 
the sovereign bond yield spread, which resulted in convergence of spreads. In their study, they observed the yield bond spread spillover by introducing indices that were based on a 10-day forecast error variance decomposition. The findings concluded that Greece was a "net transmitter" of volatility since the crisis erupted. The crisis exposed Greece's distressed debt position, which subsequently impacted investor confidence resulting in possible capital flight, and this reveals the fear of international financial contagion, which had some significant spillover effect on the European Monetary Union (EMU). Arguably, the weaker economic environment markets are the ones that face a massive brunt of disproportional high spreads. This co-movement across countries showed Portugal, Ireland, Greece, Italy, and Spain as the epicenters of contagion effects. This is further echoed in the study by Antonakakis et al. (2017) who also observed the convergence long-term effect among the Euro Area 17 economies. Other authors (Aizenman et al. 2013; Beirne and Fratzscher 2013) estimate the pricing of sovereign risk and contagion by observing 50 countries based on fiscal space (debt/tax; deficits/tax) and other economic fundamentals over the period of 2005-2010. In their findings, they concluded that market-priced risk of sovereign debt as measured by credit default swap (CDS) is partly explained by fiscal space and other economic determinants.

Moreover, previous analysis like Bardozzetti and Dottori (2014), Bradley and Gulati (2013a) contain the rating of issuers as independent variables in order to identify whether the impact of CACs differ for either lower or higher rated issuers. In their study, the authors highlighted the significance of CACs as contractual provisions that are included in the issues of sovereign bonds; hence, they do ensure that there is an orderly way to fulfil debt restructuring procedures. However, the key highlights in their findings showed that previous studies in the early 2000s showed a contrasting picture, indicating that CACs could even depress or enhance yields or have no effect at all. However, generally CACs have been used as a proxy tool, which can facilitate debt restructuring. However, they concluded that the effect of CACs on yields may vary in a non-linear fashion depending on the issuers' rating, which subsequently resulted in a U-shaped impact of CACs on yields. Interestingly, they concluded that the advantages of the CACs were much greater for the creditors of mid-rated issuers due to the fact that the probability of default was deemed to be negligible meaning that CACs are indeed valuable.

Aristei and Martelli (2014) do examine sovereign bond yields by extending the existing models commonly used in empirical analyses and they put their focus on the impact of market expectations and behavioral factors. This highlights another poignant fact relating to the literature that has been documented on sovereign bonds. In our view, the essence of examining bond yields as a result of adopting the CACs proxy can also be viewed from another perspective lenses of which the bond pattern spreads can also be influenced by consumer sentiment and expectations, in particular during a crisis as exemplified during Euro area crisis (Aristei and Martelli 2014). Their findings echo the reason why CACs were introduced; however, market authorities also need to ensure that behavioral factors are also taken into consideration when constructing mechanism decisions aimed at cushioning the spread movements. Furthermore, multiplicity models are still required to help policymakers develop more robust testing proxies, which also may influence investor sentiments.

Richards and Gugiatti (2003a) in their compelling empirical study on the defining desirable mechanisms designed to deal with sovereign debt crises, highlighted the fact that the use of CACs has been wider than previously thought. They argue that bond prices are not affected very much by the implicit (legal jurisdiction) or explicit inclusion by these types of clauses when examining yields in secondary markets (Weinschelbaum and Wynne 2005).

They find that the use of CACs in Euromarkets issues has not affected the pricing of yields on new bond issues. Moreover, they reiterated that even after debates of sovereign debt restructuring in 2002, there is no evidence that CACs do have an economically or statistically significant impact on bond yields. They come to the conclusion that investors 
still do not focus on whether bonds do include CACs or not and thus, might not believe that the inclusion of CACs has an impact on the pricing of debt.

Other studies (for example, Ghosal and Thampanishvong 2013), however, raise the imperative that potential reforms such as market-based approaches are indeed essential because they can improve creditor coordination. This will result in efficiency gains of strengthening CACs in the functioning of sovereign debt markets. Bulow and Rogoff (1989) also argue on the basis that strengthening of CACs might reduce the costs associated with debt restructuring and affect sovereign debtor incentives. Contributing to the debate on the subject of CACs, Weinschelbaum and Wynne (2005), in their study, emphasized that CACs introduce flexibility in situations of financial distress by facilitating renegotiations. Since renegotiating gives governments some relief from debt overhang, there is also a potential likelihood that the governments might "run reckless fiscal policies that can increase the likelihood of financial crisis" Weinschelbaum and Wynne (2005). They concluded that CACs can significantly increase the cost of borrowing for sovereigns, which can be viewed as an indicator that yields rise due to the presence of CACs in bond contracts. The authors make further claims that these clauses are likely to be irrelevant in sovereign debt markets, which in turn indicates that yield spreads of bonds with and without CACs are deemed uninformative about moral hazard problems.

Other studies, for example, Haldane et al. (2005), present a theoretical model by analyzing proposals on restructuring sovereign bonds. The findings reveal the evidence that "CACs inserted in bonds resolve the inefficiencies caused by intra-creditor coordination problems providing that all parties have complete information about each other's preference". This argument is consistent with the benefit effect of CACs in international bond market as echoed by Eichengreen and Portes (1985). As already discussed above, there is still considerable disagreement about precisely how CACs can impact sovereign bond yields and also whether debt restructuring benefits are captured. The research that underpins the topic under discussion has showed that prior research on CACs has produced mixed findings. The majority of the empirical theoretical evidence is presented in a synopsis table in Appendix A.

\section{Empirical Analysis \\ Data and Methodology}

The empirical analysis presented here makes an attempt to find evidence on how sovereign bond yields are affected by the newly introduced CACs in European sovereign bonds. This is because all European sovereign bonds contain CACs with effect from January 2013. Data for the analysis are obtained from Bloomberg Database covering all European sovereign bonds issued from 1940 until 2015. Ratings from Standard and Poor's Financial Services are also obtained from Bloomberg Database. Data concerning sovereign bonds are structured as follows (Table 1):

Table 1. Structuring of sovereign bonds (Source: Authors).

\begin{tabular}{cc}
\hline Bonds without CAC & Bonds including CAC \\
\hline Issue date starting from 2011 & Issue date starting from 2013 \\
Bonds issued in Euro & Bonds issued in Euro \\
Coupon type: fixed & Coupon type: fixed \\
Rating from S\&P & Rating from S\&P \\
\hline
\end{tabular}

In order to develop a sample for the analysis, a timeframe of two years is adopted for both types of bonds. Thus, the ones including CACs and the ones not including them, hence ex-ante vs. post-ante effects. The timeframe under observation for the analysis stops on 21 January 2015 as this is the date the European Central Bank (ECB) announced to purchase sovereign bonds of struggling economies in Europe. This could have a major impact on the overall analysis and could result in research bias and skewed findings. Thus, data on sovereign bonds containing CACs could only be collected from January 2013 
until January 2015. Due to this short time window, the authors chose a similar timeframe from 2011 until 2013 for data on sovereign bonds not containing CACs in order to obtain comparable data for the empirical analysis. When having collected similar bonds for the event window, the comparison is undertaken for the time between 2013 until 2015. The following Figure 1 depicts the scenario analysis.

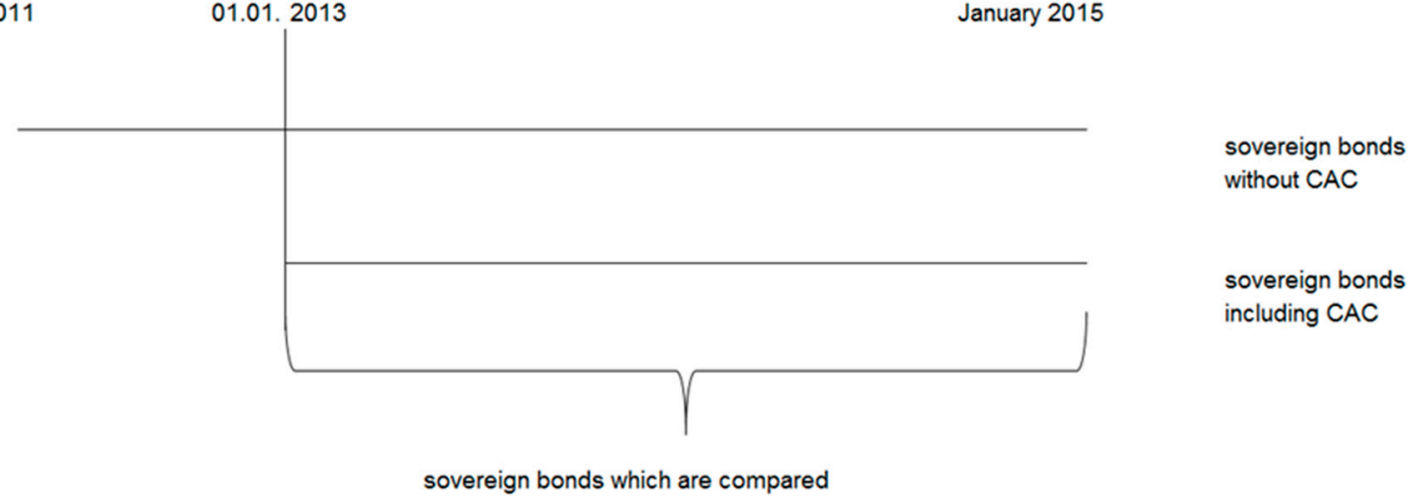

Figure 1. Event window for the empirical analysis (Source: Authors).

Excluded from the analysis are sovereign bonds issued from Greece and Cyprus. The main reason for this exclusion is a lack of data availability of bonds issued from Cyprus and the fact that Greece introduced CACs much earlier than other European countries, which could have an impact on the results as well.

In order to identify whether CACs in European sovereign bond contracts are priced on the market, a "CAC premium" is calculated. Therefore, all sovereign bonds with a maturity of five and ten years are collected from the latter sample. In a next step, comparable bonds which do and do not contain CACs are identified for each country in the sample. For each country within the sample, a CAC premium is calculated with the following formula:

$$
\text { Bond yield including } \mathrm{CAC}-\text { Bond yield without } \mathrm{CAC}=\mathrm{CACpremium}
$$

This approach is done for ten-and five-year sovereign bonds for each government separately. A negative result indicates that CACs are not priced, whereas a positive result indicates that CACs are priced in the Eurozone. This shows that the cost for sovereign bonds do rise or fall, which could be an indicator for compensating or ignoring the risk. This is in line with Bradley and Gulati (2013a) when they state in their analysis: "Economic theory makes ambiguous predictions: on the one hand, making debt easier (cheaper) to restructure could increase the propensity of governments to borrow irresponsibly, which would increase the cost of capital; on the other hand, if restructurings proceed more smoothly, creditors will receive a settlement more quickly, which would reduce the cost of capital". Drawing our analysis from this database, we demonstrate that the majority of the existing literature is based on inadequate or inappropriate data, which has led researchers to conclude that the inclusion of a CAC either has no effect or increases the cost of capital for weaker nations and decreases the cost of capital for stronger ones. In contrast, we find that the presence of CACs leads to a lower, not higher, cost of capital, especially for below-investment grade bonds.

Due to a lack of data, the CAC premium cannot be calculated for Portugal, Austria, and Spain. For the Netherlands, the CAC premium for its ten-year sovereign bond and for Italy the CAC premium for its five-year sovereign bond can be calculated. For Germany, Belgium, Finland, and France, CAC premiums for ten- and five-year sovereign bonds can be calculated.

After having calculated the CAC premium, we present and report descriptive statistics for all variables in order to obtain first results concerning the CAC premium. 
As a last step, three different regression analysis are undertaken, by adopting the Bradley and Gulati (2013a) empirical logic. The first regression is a two-stage least squares regression (2SLS regression). The 2SLS regression will address with the help of an instrument variable the possible problem of endogeneity between the variables CAC and yield (Brooks 2017). Due to different findings in the literature on how yields have an impact on CACs, (for instance Richards and Gugiatti 2003b; Eichengreen and Mody 2004; or Bradley and Gulati 2013a), the instrument variable approach is chosen to avoid a possible endogeneity problem between the variables. The regressions reflect whether there is a general relationship between yields of sovereign bonds, the CACs, and the rating of each government. The rating is chosen as an independent variable due to the fact that previous literature found that different ratings on governments had a different impact on the rise or fall of yields when CACs were used (for instance Bradley and Gulati 2013a or Bardozzetti and Dottori 2014). Therefore, the rating is introduced in this study as well, as this might have an impact on the results. For this purpose, the yields of all ten- and five-year government bonds are collected for the event window 2011 until 2015, which is used as a dependent variable (yield). The analysis is conducted for each sovereign bond, with a maturity of ten and five years, separately. The coding 0 is used for sovereign bonds not containing CACs. 1 is used for sovereign bonds that do contain CACs:

$$
\mathrm{CAC}=\left\{\begin{array}{l}
0=\text { no Collective Action Clause is included } \\
1=\text { Collective Action Clause is included }
\end{array}\right.
$$

Ratings are used as dummy variables. Due to the fact that ratings are ordinal in nature and the regression approach can only work with metric variables and dummies, they need to be recoded (Brooks 2017). Ratings for the sample of five-year sovereign bonds include the ratings AAA, AA, and $\mathrm{BBB}$. Ten-year sovereign bonds include the ratings AAA and AA. Ratingdummy5year1 to Ratingdummy5year3 are dummies for the rating categories AAA, AA, and BBB for five-year sovereign bonds. For ten-year sovereign bonds, Ratingdummy10year represents the rating category AAA. Whether the rating is positive or negative is not considered in the analysis. Those are adopted as Bradley and Gulati (2013b) did in their analysis on CACs for the Eurozone. The dummy variables for the two calculations are as followed:

Five-year sovereign bonds:

$$
\begin{aligned}
& \text { Ratingdummy5year1 }=\left\{\begin{array}{l}
1=\text { AAA } \\
0=\text { otherwise }
\end{array}\right. \\
& \text { Ratingdummy5year2 }=\left\{\begin{array}{l}
1=\text { AA } \\
0=\text { otherwise }
\end{array}\right. \\
& \text { Ratingdummy5year } 3=\left\{\begin{array}{l}
1=\text { BBB } \\
0=\text { otherwise }
\end{array}\right.
\end{aligned}
$$

Ten-year sovereign bonds:

$$
\text { Ratingdummy10year }=\left\{\begin{array}{l}
1=\text { AAA } \\
0=\text { otherwise }
\end{array}\right.
$$

The instrument variable in the 2SLS regression represents the date when CACs were introduced by the European Union, which is 1 January 2013 (Art. 12 ESM Treaty). This date has a direct impact on CACs as it is the date when the clause came into force and all sovereign bonds issued then include it. As previous literature did find evidence that credit ratings do have an impact on CACs (for instance Bradley and Gulati 2013b or Bardozzetti and Dottori 2014), the instrument variable is also used for the independent variable rating. The instrument variable is coded 0 for the date when CACs were introduced, which is "after 1st January 2013", and 1 for the date before the introduction of the clause which is "before 1st January 2013".

$$
Z=\left\{\begin{array}{l}
0=\text { after } 1 \text { st January } 2013 \\
1=\text { before1st January } 2013
\end{array}\right.
$$


The CAC and the Ratings represent the independent variables for the regressions. $\varepsilon$ and $v$ are the error terms for the regression (Brooks 2017). The following formulas are used for this analysis:

Five-year sovereign bonds:

$$
\begin{gathered}
\text { Yyield5year }=\beta \mathrm{o}+\beta \mathrm{CAC}+\beta \text { ratingdummy5year1 }+ \text { Bratingdummy5year2 } \\
+\beta \text { ratingdummy5year3 }+\varepsilon \\
\hat{X} \text { CAC }=\text { Yo }+ \text { Y1Z1date }+ \text { Y2Xratingdummy5year1 }+ \\
\text { Y3Xratingdummy5year2 }+ \text { Y4Xratingdummy5year3 }+\mathrm{v} \\
\text { Yyield5year }=\beta o+\beta 1 \hat{X} C A C+\beta \text { Xratingdummy5year1 }+ \\
\beta \text { Xratingdummy5year2 }+\beta \text { Xratingdummy5year3 }+\mathrm{v}
\end{gathered}
$$

Ten-year sovereign bonds:

$$
\begin{gathered}
\text { Yyield10year }=\beta \mathrm{o}+\beta \mathrm{CAC}+\beta \text { ratingdummy10year }+\varepsilon \\
\hat{\mathrm{X} C A C}=\text { Yo }+ \text { Y1Z1date }+ \text { Y2Xratingdummy10year }+\mathrm{v} \\
\text { Yyield5year }=\beta \mathrm{o}+\beta 1 \hat{\mathrm{XCAC}}+\beta \text { Xratingdummy10year }+\mathrm{v}
\end{gathered}
$$

Thereafter, two linear regressions are designed for the CAC premium. The dependent variable is the CAC premium and independent variables are first result and second the rating of the countries from Standard and Poor's Financial Services. Result is a variable reflecting whether the CAC premium is positive or negative. This is calculated in the first step of the analysis. The variable is coded 1 for a positive result and 0 for a negative result:

$$
\text { Result }=\left\{\begin{array}{l}
0=\text { negative } \\
1=\text { positive }
\end{array}\right.
$$

Ratings again are used as dummy variables. For five-year sovereign bonds, RatingdummyCAC5year1 to RatingdummyCAC5year3 are dummies for the rating categories AAA, AA, and BBB. RatingdummyCAC10year1 and RatingdummyCAC10year2 represents the rating category AAA and AA. The dummies are coded in the following way for each ten- and five-year sovereign bonds:

Five-year sovereign bonds:

$$
\begin{aligned}
& \text { RatingdummyCAC5year1 }=\left\{\begin{array}{l}
1=\mathrm{AAA} \\
0=\text { otherwise }
\end{array}\right. \\
& \text { RatingdummyCAC5year2 }=\left\{\begin{array}{l}
1=\mathrm{AA} \\
0=\text { otherwise }
\end{array}\right. \\
& \text { RatingdummyCAC5year3 }=\left\{\begin{array}{l}
1=\mathrm{BBB} \\
0=\text { otherwise }
\end{array}\right.
\end{aligned}
$$

Ten-year sovereign bonds:

$$
\begin{aligned}
& \text { RatingdummyCAC10year1 }=\left\{\begin{array}{l}
1=\mathrm{AAA} \\
0=\text { otherwise }
\end{array}\right. \\
& \text { RatingdummyCAC10year2 }=\left\{\begin{array}{l}
1=\mathrm{AA} \\
0=\text { otherwise }
\end{array}\right.
\end{aligned}
$$

Hence, the formulas for the multiple linear regressions are represented as: Five-year sovereign bonds:

YCACpremium5year $=\beta o+\beta$ result $+\beta$ ratingdummyCAC5year1

$+\beta$ ratingdummyCAC5year2 + $\beta$ ratingdummyCAC5year3

Ten-year sovereign bonds:

YCACpremium10year $=\beta o+\beta$ result $+\beta$ ratingdummyCAC10year1

$$
+\beta \text { ratingdummyCAC10year2 }
$$


where, as explained before, the CAC premium represents the dependent variable. The first independent variable "result" and the remaining independent variables, the rating dummies. The determinants $\beta^{\circ}$ represents the intercept of the dependent variable and $\beta$ the slope of the regression line (Ruppert 2004).

This is done in two different ways. First, the dependent variable represents only CAC premiums for five-year sovereign bonds. Second, the dependent variable is the CAC premium for ten-year government bonds. The reason for undertaking the analysis in two different ways is due to the lack of data availability. The sample of government bonds, which include CACs and could be compared to bonds that do not contain the clause, is small; therefore, the authors run several analyses in order to identify whether the results are equal for all the different possibilities.

As previous literature analyzed a relationship between CAC and ratings, for instance (Bradley and Gulati 2013b) or (Bardozzetti and Dottori 2014), a possible correlation between the variables CAC premium and rating is tested. This step is undertaken in order to reduce the risk of the impact of a possible correlation between the variables, which could have an impact on the analytical findings. Therefore, multicollinearity between the two variables is tested as a first step. As a test for multicollinearity, the variance inflation factor (VIF) is used (Ruppert 2004).

As we attempt to find the relationship between the variables yields, $\mathrm{CAC}$, and rating for each five- and ten-year sovereign bonds, the null hypothesis for the first analysis is that there is no relationship between the five-year government sovereign bond yields, whether bonds do contain CACs or not and the rating. The second null hypothesis shows the relationship between the variables $\mathrm{CAC}$, rating, and ten-year sovereign bond yields; hence:

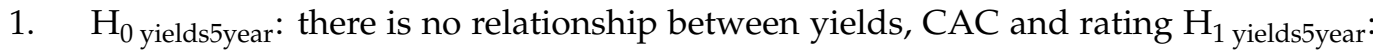
there is a relationship between yields, CAC and rating

2. $\mathrm{H}_{0 \text { yields10year }}$ : there is no relationship between yields, $\mathrm{CAC}$ and rating $\mathrm{H}_{1 \text { yields10year: }}$ there is a relationship between yields, CAC and rating

Furthermore, for the CAC premium, we are looking for a relationship between the variables $C A C$ premium, result, and rating for each, five and ten-year sovereign bonds. Therefore, the third null hypothesis is that there is no relationship between the CAC premium, the variable result, and the rating for five-year sovereign bonds. The fourth null hypothesis shows whether there is a relationship between the variables CAC premium, result, and the rating for ten-year sovereign bonds.

3. $\mathrm{H}_{0}$ CACpremium5years: there is no relationship between CAC premium, result and rating $\mathrm{H}_{1}$ Cpremium5years: there is a relationship between CAC premium, result and rating

4. $\mathrm{H}_{0}$ CACpremium10years: there is no relationship between CAC premium, result and rating $\mathrm{H}_{1}$ CACpremium10years: there is a relationship between CAC premium, result and rating

It is assumed the null hypothesis can be rejected, which means there is a relationship between all variables, which could be an indicator that CACs are recognized by investors and therefore, have an impact on sovereign bond yields. Differences in the pricing should be reflected by a rating, which means that poorer rated countries should be priced higher than more creditworthy countries. The results of the empirical analysis are demonstrated in the following section.

\section{Statistical Results}

\subsection{CAC Premium}

The first step of the analysis is to calculate the CAC premium for the different sovereign bonds issued between 2011 and 2015 with a maturity of either five or ten years. In the appendices, two tables are shown with first the summary calculations of the CAC premium for sovereign bonds maturing after five years, and second a table with the CAC premium for sovereign bonds maturing after ten years. Through these calculations, first results can 
be determined on how the yields are affected by CACs and whether CACs are priced on financial markets or not.

As shown in both Tables A2 and A3, there are positive and negative results for the CAC premium. As explained in the latter section, a negative result indicates that CACs are not priced whereas a positive result shows that CACs are priced on the market. Through both calculations, it can be said that CACs are priced for all sovereign bonds, except for those issued from Germany. Within the sample used for the empirical analysis, Germany is the only government-rated AAA, which is the best rating in the sample. All governments rated less than AAA, highlighting a positive result for the CAC premium. In addition, Bradley and Gulati (2013b) found in their empirical analysis that when including CACs in sovereign bond contracts, yields rise for lower rated issuers. As Germany has the best rating in the sample and $\mathrm{AA}$ and $\mathrm{BBB}$ represent the worst ratings within the sample, it can be said that the findings through the analysis of the CAC premium are constant with the findings resulting from the analysis of Bradley and Gulati (2013b). Thus, CAC premiums are present for governments with a rating between AA and BBB.

\subsection{Descriptive Statistics}

The full tables of the descriptive statistics for the CAC premium of five- and ten-year government bonds and the yields can be found in the appendices. Here, a summary table (Table 2) of the most important findings is given:

Table 2. Summary of descriptive statistics CACs (Source: Authors).

\begin{tabular}{ccccc}
\hline Variables & Observations & Mean & Standard Deviation & Standard Error \\
\hline Yields & 84 & 0.206 & 0.598 & 0.065 \\
CAC premium 5-year bonds & 19 & 0.177 & 0.346 & 0.079 \\
CAC premium 10-year bonds & 14 & 0.12 & 0.135 & 0.036 \\
\hline
\end{tabular}

Regarding the mean of the CAC premium for five-and ten-year sovereign bonds, that of the ten-year sovereign bonds is smaller with a value of 0.12 , compared to the five-year sovereign bonds with 0.177 . Even if there is only a small difference of 0.057 , it can be concluded that CAC premiums for sovereign bonds maturing after five years are higher than those for ten-year sovereign bonds. Hence, the price demanded for government bonds, which include CACs in their bond contracts and have a maturity of five years, bring higher yields to investors than those running ten years. With a standard deviation of 0.346 for the CAC premium of five-year sovereign bonds and 0.135 for the CAC premium of ten-year sovereign bonds, the data values of the analysis are all close to the mean. When observing the yields in general, a mean of 0.206 and a standard deviation of 0.598 are determined.

\subsection{Regression Analysis}

5.3.1. Two-Stage Least Squares Regression Analysis on Yields of Five- and Ten-Year Sovereign Bonds

The analysis of variance tables (ANOVA) of the 2SLS regressions for the yields of five- and ten-year sovereign bonds as well as the full statistical results are shown in the appendices for each five- and ten-year sovereign bonds. In Table 3, a summary of all findings is given:

Table 3. Summary findings of 2SLS regression (Source: Authors).

\begin{tabular}{cccccc}
\hline Variables & $\begin{array}{c}\text { Confidence } \\
\text { Level }\end{array}$ & Significance & $\mathbf{R}^{2}$ & VIF & $\begin{array}{c}\text { Standard } \\
\text { Error }\end{array}$ \\
\hline 5-year bonds & $95 \%$ & $0.5 \%<5 \%$ & $18 \%$ & 1.12 & 0.059 \\
10-year bonds & $95 \%$ & $0.2 \%<5 \%$ & $37 \%$ & 1.06 & 0.032 \\
\hline
\end{tabular}


Overall analysis for yield as dependent variable shows that the null hypothesis can be rejected in both ways for five- and ten-year sovereign bonds with a confidence level of $95 \%$, which means that there is a relationship between yields, CAC, and the rating. With a $p$-value of less than $5 \%$ in all findings, the results show a statistical significance. Given the $\mathrm{R}^{2}$ of the five-year sovereign bonds, $18 \%$ of the variability of the dependent variable yield is explained by the explanatory variable. For ten-year sovereign bonds, $37 \%$ of the variability of the dependent variable yield is explained by the explanatory variable. In both calculations, multicollinearity does not indicate a severe problem with a variance inflation factor (VIF) of 1.12 for five-year sovereign bonds and a VIF 1.06 for ten-year sovereign bonds. The small standard error of both calculations of 0.059 for five-year sovereign bonds and 0.032 for ten-year sovereign bonds shows that the mean is relatively close to the true mean of the overall population.

The correlation matrix of both calculations can be found in the appendices. When having a greater observation at the single variables and their impact on yields, it can be determined that the variables have a greater impact on ten-year sovereign bonds. Nevertheless, it can be concluded that CACs do have a positive impact on yields ( 0.43 for five-year sovereign bonds and 0.65 for ten-year sovereign bonds). For the five-year sovereign bonds, regarding Ratingdummies, it can be said that high ratings have a negative impact on yields and lower ratings a positive one with a correlation of -0.192 for Ratingdummy 1 and -0.181 for Ratingdummy2. However, Ratingdummy3 shows a weak positive trend. Compared to this, the ten-year sovereign bonds show a higher correlation with 0.61 for the CAC and -0.798 for the Ratingdummy. Because simple correlations could be misleading as they do not consider the dependence on other independence variables, the VIF test was used in advance to detect the severity of multicollinearity because it inflates the variance and type II error and therefore, this problem was avoided.

\subsubsection{CAC Premium, Test for Multicollinearity, and Regression Analysis}

In the appendices, the summary statistics of the multicollinearity of the CAC premium and the independent variable result as well as the regression analysis for ten- and five-year sovereign bonds are shown. In the following Table 4, a summary of all findings is provided:

Table 4. Summary findings linear regression and multicollinearity (Source: Authors).

\begin{tabular}{cccccc}
\hline Variable & $\begin{array}{c}\text { Confidence } \\
\text { Level }\end{array}$ & Significance & $\mathbf{R}^{2}$ & VIF & $\begin{array}{c}\text { Standard } \\
\text { Error }\end{array}$ \\
\hline CAC premium 5-year bonds & $95 \%$ & $2.2 \%<5 \%$ & $38 \%$ & 1.6 & 0.079 \\
CAC premium 10-year bonds & $95 \%$ & $0.2 \%<5 \%$ & $55 \%$ & 2.24 & 0.036 \\
\hline
\end{tabular}

In both calculations, for the CAC premium for ten- and five-year sovereign bonds, it can be said that multicollinearity is still on a good level with a VIF of 2.24 for ten-year sovereign bonds and a VIF of 1.6 for five-year sovereign bonds, which is not so high to bias the results. The findings show that the there is no severe problem with multicollinearity. Moreover, for the CAC premium, a relatively small standard error of 0.079 for five-year sovereign bonds and 0.036 for ten-year-sovereign bonds indicates that the mean is close to the true mean of the overall population.

The results of the ANOVA for each, the CAC premium of ten- and five-year sovereign bonds, are shown in the appendices.

The CAC premium for five-year sovereign bonds shows that the $\mathrm{R}^{2}, 38 \%$ of the variability of the dependent variable CAC premium is described by the two explanatory variables. Given the $p$-value of the F statistic, which is $2 \%$, computed in the ANOVA table, and given the significance level of $5 \%$, the information brought by the explanatory variables is significantly better than what a basic mean would bring. For ten-year sovereign bonds, the findings on the CAC premium indicates that $55 \%$ of the variability of the dependent variable CAC premium is explained by the explanatory variable. Given the $p$-value of the F statistic computed in the ANOVA table, and given the significance level of $5 \%$, 
the information brought by the explanatory variables is significantly better than what a basic mean would bring. Therefore, a relationship between the variables CAC premium, result, and ratings can be concluded for each, five- and ten-year sovereign bonds, and null hypothesis can be rejected in both ways with a confidence level of $95 \%$.

The correlation matrix for each calculation for five- and ten-year sovereign bonds can be seen in the appendices. Here again, the results of the relationship of the single variables on the dependent variable shows that ten-year sovereign bonds have a more significant correlation. For five-year sovereign bonds, the CAC premium and variable result show a weak positive trend. Ratingdummiy1 and Ratingdummy2 show a weak negative trend. Ratingdummy3 depicts a positive trend with 0.604 . For ten-year sovereign bonds, the relation between the CAC premium and the variable result has a positive correlation with 0.744 . Ratingdummy1 shows a negative correlation with -0.774 and the Ratingdummy2 indicates a positive trend with 0.744 . In this calculation, the VIF is used as well to avoid a misleading result as the correlation could interfere with the impacts of the cause and effect.

Table 5 depicts the results of the null hypothesis:

Table 5. Summary of key empirical findings (Source: Authors).

\begin{tabular}{|c|c|}
\hline Hypothesis & Findings \\
\hline $\begin{array}{l}\text { H1: is there a relationship between the variables } \\
\text { yields of five-year sovereign bonds, CAC, and } \\
\text { rating? }\end{array}$ & $\begin{array}{l}\text { there is a relationship between the variables } \\
\text { yields of five-year sovereign bonds, CAC, and } \\
\text { rating }\end{array}$ \\
\hline $\begin{array}{l}\text { H2: is there a relationship between the variables } \\
\text { yields of ten-year sovereign bonds, CAC, and } \\
\text { rating? }\end{array}$ & $\begin{array}{l}\text { there is a relationship between the variables } \\
\text { yields of ten-year sovereign bonds, CAC, and } \\
\text { rating }\end{array}$ \\
\hline $\begin{array}{l}\text { H3: is there a relationship between CAC premium, } \\
\text { result, and rating for five-year sovereign bonds? }\end{array}$ & $\begin{array}{l}\text { there is a relationship between CAC premium, } \\
\text { result, and rating for five-year sovereign bonds }\end{array}$ \\
\hline $\begin{array}{l}\text { H4: is there a relationship between CAC premium, } \\
\text { result, and rating for ten-year sovereign bonds? }\end{array}$ & $\begin{array}{l}\text { there is a relationship between CAC premium, } \\
\text { result, and rating for ten-year sovereign bonds }\end{array}$ \\
\hline
\end{tabular}

\section{Empirical Results}

The analysis shows that with the inclusion of CACs in European sovereign bond contracts since January 2013, a CAC premium is paid for governments rated below AAA, which indicates that CACs in Europe are priced on financial markets. There is evidence that European sovereign bond yields respond to the inclusion of CACs in sovereign bond contracts, which indicates that yields for both five- and ten-year sovereign bonds are affected by the introduction of CACs in Europe. Especially for ten-year sovereign bonds, the correlation between the sovereign bond yields and whether there is a CAC included shows a moderate positive effect, which indicates that the yield rises with the inclusion of CACs in sovereign bond contracts. In addition, there is evidence of a relationship between the variables result and the CAC premium for each five- and ten-year sovereign bonds. Again, especially for ten-year sovereign bonds, the correlation between the variables is more significant than for five-year sovereign bonds. A positive result has an uphill relationship with the CAC premium. Regarding the ratings, it can be said that the lower the rating, the higher the correlation in both analyses. This means that the lower the rating, the higher the impact on yields and the CAC premium. Hence, there is a CAC premium demand in the market and a relationship between European sovereign bond yields and the inclusion of CACs in Europe. Furthermore, whether this premium is positive or negative is statistically significant. The results obtained from the empirical analysis indicate that investors in Europe recognize CACs in European sovereign bonds. Due to the fact that European governments are able to restructure debts by a majority voting through the inclusion of CACs, investors have faced a higher risk when investing in European sovereign bonds since January 2013. The empirical results also demonstrate that due to the higher risks, investors demand a CAC premium and further sovereign bond yields respond 
to the inclusion of CACs. This again reflects the investor sentiment that they do recognize the clause and the impact it might have on their investments. Further evidence is found for the impact CACs has on government bonds, which is also consistent with previous literature such as the findings of Becker et al. (2003) or Richards and Gugiatti (2003a).

\section{Conclusions}

This study made an attempt to determine the impact of CACs on European sovereign bond yields. It explored the impact by observing the changes over the time period indicated in the study. Uniform CACs were introduced in sovereign bond contracts issued from member states of the European Union aiming to restructure debts in case struggling governments face financial difficulties. The overall aim of introducing these interventions was designed to "cushion" the economies from another possible debt crisis that had crippled economies in the past.

The study sheds light on the effects of the introduction of European CACs in European sovereign bond contracts on sovereign bond yields and the pricing of the newly introduced clause. Since January 2013, when the new clause on European sovereign bond contracts was launched, investors have faced a higher risk when buying sovereign bonds as the clause permits, with the help of a majority vote, to restructure debts (Art. 12 ESM Treaty). Thus, in this study, we have made an attempt to address the impact CACs have on sovereign bond yields with a maturity of either five- and ten-years. Moreover, it is analyzed whether a CAC premium is demanded for the higher risk and whether this has a relation with the variables rating and research findings.

The statistical results of the study undertaken on whether European sovereign bond yields respond to the inclusion of CACs in European sovereign bonds with a maturity of five- and ten-years each show that there indeed is a relationship between the inclusion of the newly introduced clause and sovereign bond yields. This indicates that European sovereign bond yields do respond to the inclusion of CACs and that sovereign bond yields are influenced by the newly introduced clause. In addition, this relationship is higher for ten-year sovereign bonds compared to five-year sovereign bonds. Moreover, a relationship between the variables Result and CAC premium for five- and ten-year sovereign bonds is found. Here as well, the relationship for ten-year sovereign bonds shows a greater impact than those of five-year sovereign bonds. Therefore, it can be concluded that a CAC premium is demanded since the clause came into force in Europe. Whether this premium is positive or negative is statistically significant and a relationship between European sovereign bond yields and the inclusion of CACs in Europe is found. Finally, it can be concluded that the European CACs are recognized in financial markets. Due to a higher risk caused by a possible majority voting and restructuring of debts, investors' demand for a CAC premium since January 2013 and sovereign bond yields respond to the inclusion of CACs.

As CACs are part of all European government bonds issued after January 2013 and the empirical analysis for this study ends in January 2015, there is a short event window of only two years. Data for the analysis are sparse for the timeframe that is under observation. This might have an impact on the results. For future analysis on the topic about whether European CACs for European sovereign bonds are priced in financial markets, it is recommended to undertake a second similar analysis to the one described in this study, and extend the time observation period and increase the sample scope in order to capture a more robust perspective on the impact of CACs. Therefore, it is recommended to undertake a similar analysis in future when more data on government bonds containing CACs in Europe are available. As Wiesmann (2013) states in his article on CACs and the restructuring of sovereign debt, it might take two to three decades until a migration towards a $100 \%$ of bonds issued with CACs is reached in Europe. Today, we recently experienced the first sovereign bonds issued with the inclusion of CACs in Europe. As the analysis indicates, investors indeed do recognize CACs in Europe and sovereign bond yields do respond to the introduction of the clause in European sovereign bond contracts. 
Author Contributions: Conceptualization, N.L.; formal analysis, E.S.; investigation, N.L.; writingoriginal draft preparation, E.S. and N.L.; writing-review and editing, E.S. and N.L; supervision, E.S. All authors have read and agreed to the published version of the manuscript.

Funding: This research received no external funding.

Conflicts of Interest: The authors declare no conflict of interest.

\section{Appendix A. Synopsis Table}

Table A1. Synopsis studies on CACs, sovereign debt, and sovereign yield spreads (Source: Authors).

\begin{tabular}{|c|c|c|c|}
\hline Authors & Study & Methodology & Key Findings \\
\hline $\begin{array}{l}\text { Grossman and Van } \\
\text { Huyck (1985) }\end{array}$ & $\begin{array}{l}\text { Analyses a reputational } \\
\text { equilibrium in a model that } \\
\text { interprets sovereign debts as } \\
\text { contingent claims that both } \\
\text { finance investments and } \\
\text { facilitate risk shifting. The } \\
\text { paper develops an analysis of } \\
\text { sovereign debt that interprets } \\
\text { outcomes involving sovereign } \\
\text { default as reflecting implicit } \\
\text { understandings that a } \\
\text { borrower may justifiably } \\
\text { adjust its debt servicing } \\
\text { obligations if the realized state } \\
\text { of the world turns out to be } \\
\text { unusually bad for the } \\
\text { borrower. }\end{array}$ & Regression analysis & $\begin{array}{l}\text { A key aspect of the analysis is that } \\
\text { lenders differentiate excusable default, } \\
\text { which is associated with implicitly } \\
\text { understood contingencies, from } \\
\text { unjustifiable repudiation. The factors } \\
\text { that tend to produce a binding lending } \\
\text { ceiling include a high time discount } \\
\text { rate for the sovereign, low-risk } \\
\text { aversion for the sovereign, and a low } \\
\text { net return from the sovereign's } \\
\text { investments. The present paper derives } \\
\text { the properties of a reputational } \\
\text { equilibrium in a model in which } \\
\text { sovereign debts serve to share risks to } \\
\text { the mutual advantage of borrowers and } \\
\text { lenders, as well as to finance } \\
\text { investments }\end{array}$ \\
\hline $\begin{array}{l}\text { Eichengreen and } \\
\text { Portes (1985) }\end{array}$ & $\begin{array}{l}\text { They analyze the debt crisis of } \\
\text { the 1930s to see what light this } \\
\text { historical experience sheds on } \\
\text { recent difficulties in } \\
\text { international capital markets. }\end{array}$ & $\begin{array}{l}\text { Comparing the performance } \\
\text { of standard models of foreign } \\
\text { borrowing models of debt } \\
\text { capacity to the circumstances } \\
\text { of the interwar years }\end{array}$ & $\begin{array}{l}\text { They provide the first estimates of the } \\
\text { realized rate of return on foreign loans } \\
\text { floated between the wars, based on a } \\
\text { sample of dollar and sterling bonds } \\
\text { issued in the } 1920 \text { s. }\end{array}$ \\
\hline $\begin{array}{c}\text { Bulow and Rogoff } \\
\text { (1989) }\end{array}$ & $\begin{array}{c}\text { Presents a model of the } \\
\text { on-going bargaining process } \\
\text { that determines repayment } \\
\text { levels. }\end{array}$ & $\begin{array}{l}\text { To develop a simple but more } \\
\text { realistic model of sovereign } \\
\text { default Simple OLS }\end{array}$ & $\begin{array}{l}\text { The ability to credibly threaten more } \\
\text { draconian penalties in the event of } \\
\text { repudiation may be of no benefit to } \\
\text { lenders. Also, unanticipated increases } \\
\text { in world interest rates may actually } \\
\text { help the borrowers by making lenders } \\
\text { more impatient for a negotiated } \\
\text { settlement. }\end{array}$ \\
\hline Atkeson (1991) & $\begin{array}{c}\text { To examine the constrained } \\
\text { optimal pattern of capital } \\
\text { flows between a lender and a } \\
\text { borrower in an environment } \\
\text { in which there are two } \\
\text { impediments to forming } \\
\text { contract }\end{array}$ & Simple OLS & $\begin{array}{l}\text { The first impediment to contracting } \\
\text { arises from the assumption that lenders } \\
\text { cannot observe whether borrowers } \\
\text { invest or consume borrowed funds. } \\
\text { This assumption leads to a moral } \\
\text { hazard problem in investment. The } \\
\text { second impediment arises from the } \\
\text { assumption that the borrower, as a } \\
\text { sovereign nation, may choose to } \\
\text { repudiate his debts. }\end{array}$ \\
\hline Becker et al. (2003) & $\begin{array}{l}\text { The study examines the } \\
\text { pricing of bonds with and } \\
\text { without CACs using data for } \\
\text { both primary and secondary } \\
\text { market yields }\end{array}$ & $\begin{array}{l}\text { Simple OLS regressions; } \\
\text { primary and secondary } \\
\text { market data }\end{array}$ & $\begin{array}{l}\text { No evidence is found that the presence } \\
\text { of CACs has increased yields for either } \\
\text { higher- or lower-rated issuers. }\end{array}$ \\
\hline
\end{tabular}


Table A1. Cont.

\begin{tabular}{|c|c|c|c|}
\hline Authors & Study & Methodology & Key Findings \\
\hline $\begin{array}{l}\text { Richards and } \\
\text { Gugiatti (2003a) }\end{array}$ & $\begin{array}{l}\text { Investigated for a sample } \\
\text { period from 1994-2003 how } \\
\text { financial markets have priced } \\
\text { the use and non-use of CACs } \\
\text { in emerging market bonds. }\end{array}$ & Simple OLS & $\begin{array}{l}\text { They find that the use of CACs in } \\
\text { Euromarkets issues has not affected the } \\
\text { pricing of yields on new bond issues. } \\
\text { Moreover, they argue that even after } \\
\text { debates of sovereign debt restructuring } \\
\text { in } 2002 \text { there is no evidence found that } \\
\text { CACs do have an economically or } \\
\text { statistically significant impact on bond } \\
\text { yields. They come to the conclusion } \\
\text { that investors do still not focus on } \\
\text { whether bonds do include CACs or not } \\
\text { and thus might not believe that the } \\
\text { inclusion of CACs does have an impact } \\
\text { on the pricing of debt. }\end{array}$ \\
\hline $\begin{array}{l}\text { Richards and } \\
\text { Gugiatti (2003b) }\end{array}$ & $\begin{array}{l}\text { The study conducted an } \\
\text { analysis in order to find } \\
\text { evidence of the use of CACs } \\
\text { in New York law bonds of } \\
\text { sovereign issuers. }\end{array}$ & Simple OLS regression & $\begin{array}{l}\text { With this analysis, the authors find } \\
\text { further support for their previous } \\
\text { evidence that CACs do not affect bond } \\
\text { pricing. They indicate that it is difficult } \\
\text { to recognize how CACs have been } \\
\text { priced if at the same time investors are } \\
\text { not aware of which bonds do contain } \\
\text { CACs and which do not. }\end{array}$ \\
\hline
\end{tabular}

Find more evidence with a study covering a comparison

of launch spreads on emerging market bonds which are subject to English law and which do include CACs with

launch spreads of bonds subject to United States law and contrary do not include CACs
The study shows that CACs reduce borrowing costs for more creditworthy issuers. Less creditworthy issuers in contrast pay higher spreads when CACs are present in bond contracts.
Analyzed how CACs determine the governments' fiscal incentives, government bond prices and default probabilities in environments with and without contingent debt and the presence of the International Monetary Fund.
Simple OLS regression
Weinschelbaum and Wynne (2005)
The paper develops a simple theoretical model to analyze recent proposals on restructuring of sovereign

$$
\text { bonds. }
$$

They found that CACs can increase significantly the cost of borrowing for sovereigns which could be seen as an indicator that yields rise due to the presence of CACs in bond contracts.

Haldane et al. (2005)

Simple OLS

CACs inserted in bonds resolve the inefficiencies caused by intra-creditor coordination problems providing that all parties have complete information about each other's preferences. This is

Simple theoretical model no longer the case when the benefits from reaching a restructuring agreement are private information to the debtor and its creditors due to inefficiencies caused by the debtor-creditor bargaining problem.

Sovereign debt crises are and will continue to be difficult policy problems for the "international community", reason is the sovereignty of the 
Table A1. Cont.

\begin{tabular}{cc}
\hline Authors & Study \\
\hline & \\
& Study of the determinants of \\
Bernoth and & sovereign bond yield spreads \\
Erdogan (2012) & across 10 EMU countries \\
& between Q1/1999 and \\
Q1/2010.
\end{tabular}

Semiparametric time-varying coefficient model to identify to what extend an observed change in the yield spread is due to a shift in macroeconomic fundamentals or due to altering risk pricing.
The study addressed the question on what would be

Bradley and Gulati (2013a) the effect of including CACs in all Eurozone sovereign bonds.
Examining the historical relation between CACs and the yields on bonds written under New York and English law
Analysis of the determinants of sovereign bond yields in 22 advanced economies over the 1980-2010 period.
Panel co-integration techniques
Key Findings

In the beginning of EMU, the government debt level and the general investor's risk aversion had a significant impact on interest differentials. In the subsequent years, financial markets paid less to the fiscal position of a country. By the end of 2006, financial markets paid again attention to the fiscal position of a country (especially Germany as a safe market). In 2007, the market reaction to fiscal loosening increased considerably. The altering in risk pricing over time confirms the need of time-varying coefficient models in this context.

The authors find that CACs are indeed associated with lower rates for sovereigns in the worst financial condition. increase in government bond yields. In the short run, sovereign bond yields deviate from the level determined by the long-run fundamentals, but about half of the deviation adjusts in one year. When considering the impact of the global financial crisis on sovereign borrowing costs in EU area countries, the estimations suggest that spreads against Germany in some EU periphery countries exceeded the level determined by fundamentals in the aftermath of the crisis, while some North European countries have benefited from "safe-haven" flows.

\begin{tabular}{|c|c|c|c|}
\hline $\begin{array}{l}\text { Ghosal and } \\
\text { Thampanishvong } \\
\text { (2013) }\end{array}$ & $\begin{array}{l}\text { Question whether improving } \\
\text { creditor coordination by } \\
\text { strengthening CACs lead to } \\
\text { efficiency gains in the } \\
\text { functioning of sovereign bond } \\
\text { markets. }\end{array}$ & $\begin{array}{l}\text { Model featuring both debtor } \\
\text { moral hazard and creditor } \\
\text { coordination under } \\
\text { incomplete information. }\end{array}$ & $\begin{array}{l}\text { Once the impact of strengthening CACs } \\
\text { on debtor's incentives is taken into } \\
\text { account, the authors demonstrate the } \\
\text { robust possibility of a conflict between } \\
\text { ex ante and interim efficiency. }\end{array}$ \\
\hline $\begin{array}{l}\text { Bradley and Gulati } \\
\text { (2013a) }\end{array}$ & $\begin{array}{l}\text { The paper assesses the likely } \\
\text { effect of this proposal on the } \\
\text { borrowing costs of Eurozone } \\
\text { countries. }\end{array}$ & $\begin{array}{l}\text { Second article about the likely } \\
\text { effect CACs pose on the } \\
\text { borrowing costs of sovereign } \\
\text { debtors. }\end{array}$ & $\begin{array}{l}\text { In this article, the authors found as well } \\
\text { evidence that CACs leads to a lower } \\
\text { cost of capital, especially for } \\
\text { below-investment grade bonds. }\end{array}$ \\
\hline $\begin{array}{l}\text { Aguiar and Amador } \\
\qquad(1938)\end{array}$ & $\begin{array}{c}\text { The study explores key issues } \\
\text { in the economics of sovereign } \\
\text { debt. }\end{array}$ & $\begin{array}{c}\text { A benchmark } \\
\text { limited-commitment model }\end{array}$ & $\begin{array}{l}\text { The model is used to discuss debt } \\
\text { overhang, risk sharing, and capital } \\
\text { flows in an environment of limited } \\
\text { enforcement. They discuss recent } \\
\text { progress on default and renegotiation; } \\
\text { self-fulfilling debt crises; and } \\
\text { incomplete markets and their } \\
\text { quantitative implications. }\end{array}$ \\
\hline
\end{tabular}


Table A1. Cont.

\begin{tabular}{cc}
\hline Authors & Study \\
\hline Gelpern and Gulati & $\begin{array}{c}\text { The investigation sheds light } \\
\text { on why to promote CACs at } \\
\text { all, and cast them in such a } \\
\text { central role in the market } \\
\text { reform initiative }\end{array}$ \\
\end{tabular}

Methodology

Interviews with participants in the initiative and those affected by it, as well as observations at policy and academic meetings
Examination of sovereign bond yield spread spill overs between Euro zone countries during a period covering the global financial crisis and the Euro zone debt crisis.
VAR-based spill over index approach of Diebold and Yilmaz (2012) and impulse response analysis
Paper investigates the determinants of sovereign bond yield spreads in the

Aristei and Martelli (2014) Euro area and focusing on the impact of market expectations and behavioural factors.
Using monthly panel data for ten EU countries over the period 2000-2012, the analysis adopts a pooled mean-group approach to estimate non-stationary dynamic models of spreads determinants, allowing for country heterogeneities in short-run dynamics.
The lesson on CACs so far is in the power of seemingly minor private law techniques to shape public markets and institutions, often in non-transparent ways-and in the way contracts are shaped by their public mission.

Bond yield spread shocks tend to increase future bond yield spreads and are related to news announcements and policy changes Bond yield spreads spill overs between Euro zone countries are highly intertwined. Bond yield spread shocks from the periphery have on average three times the destabilizing force on other countries than shocks coming from the core The within-effect of bond yield spread spill overs is of greater magnitude within the periphery than that within the core. The between-effect of bond yield spread spill overs suggests directional spill overs of greater magnitude from the periphery to the Euro zone core than vice versa. Joint shocks in the periphery and the core reveal decoupling effects between these two groups of countries Overall, the findings highlight the increased vulnerability of the Euro zone from the destabilizing shocks originating mostly from the Euro zone countries in the periphery and to a lesser extent from the Euro zone core.

The behavioural indicators considered, proxies of consumer and market sentiment and expectations, strongly affect spreads behaviour, especially during the crisis.
In the paper it is argued that unconventional approaches should also be considered in

Werner (2014) sovereign debt management, in order to contribute to resolving the EU sovereign debt crisis.
Features of an ideal alternative funding tool are identified
It is found that the funding method can be implemented as part of enhanced public debt management by each nation's debt management office. 
Table A1. Cont.

\begin{tabular}{|c|c|c|c|}
\hline Authors & Study & Methodology & Key Findings \\
\hline $\begin{array}{c}\text { Bardozzetti and } \\
\text { Dottori (2014) }\end{array}$ & $\begin{array}{l}\text { The study focused on the } \\
\text { effect of the adoption of CACs } \\
\text { on government bond yields. }\end{array}$ & $\begin{array}{l}\text { Panel data approach and } \\
\text { exploit secondary market data } \\
\text { on sovereigns quoted in } \\
\text { international markets from } \\
2007 \text { to } 2010\end{array}$ & $\begin{array}{l}\text { They find a U-shaped relation between } \\
\text { the effect of CACs and bond yields and } \\
\text { the ratings of the governments. Hence, } \\
\text { CACs tend to lower yields for middle } \\
\text { ratings. When moving to the extremes } \\
\text { of ratings, this effect tends to become } \\
\text { weaker. They argue that CACs are } \\
\text { helpful for ordered restructuring, but } \\
\text { also less valuable when the probability } \\
\text { of default is very small, hence for less } \\
\text { rated issuers, or the moral hazard risk } \\
\text { is very high, which is the case for worst } \\
\text { rated issuers. }\end{array}$ \\
\hline
\end{tabular}

Evidence for a level break in the co-integrating relationship is found. Fiscal imbalances are the main long-run drivers of sovereign spreads. Liquidity

risks and cumulated inflation differentials have non-negligible weights. All conclusions are ultimately connected to whether or not the sample

Costantini et al. (2014)

Analysis of the determinants of sovereign bond yield spreads in nine economies of the EU Monetary Union.

Panel co-integration approach of countries is composed members of an Optimal Currency Area (OCA).

Results are overall driven by countries not passing the OCA test and that investors closely monitor and severely punish the deterioration of expected debt positions of those economies exhibiting significant gaps in competitiveness.

The empirical results indicate that the German stock index return, the Euro Interbank Offered Rate, stock index returns of these countries, S\&P 500 returns, VIX and sovereign debt ratings have had significant impacts on the bond yield spreads and/or volatilities, particularly in the post-crisis period.

Moreover, evidence of financial contagion effect among the peripheral countries is found.

Explicit multifactor model of equity returns extended with a sovereign risk factor. Smooth Transition Regression (STR) framework that allows for an endogenous definition of crisis periods and captures the changes in parameters associated with shift contagion.
The negative impact of the European sovereign debt crisis on banks' equity returns has been mostly confined to EU banks. US banks appear to be unharmed by its direct impact and may have even benefited from it. Evidence of shift contagion is found across Europe. 
Table A1. Cont.

\begin{tabular}{|c|c|c|c|}
\hline Authors & Study & Methodology & Key Findings \\
\hline $\begin{array}{l}\text { Antonakakis et al. } \\
\text { (2017) }\end{array}$ & $\begin{array}{l}\text { Examination of the } \\
\text { convergence patterns of Euro } \\
\text { Area } 17 \text { countries' sovereign } \\
\text { bond yield spreads over the } \\
\text { period 2002-2015. }\end{array}$ & Convergence algorithm & $\begin{array}{l}\text { Empirical findings suggest rejection of } \\
\text { full convergence across the EA17 } \\
\text { countries' bond yields spreads and the } \\
\text { presence of a certain number of clubs. } \\
\text { The transitional curves indicate that, } \\
\text { despite short-run divergences, EU17 } \\
\text { sovereign bond yield spreads tend to } \\
\text { converge in the long-run, with the } \\
\text { exception of those in Greece and } \\
\text { Cyprus, indicating the strong attempts } \\
\text { of most of the countries under } \\
\text { investigation to adopt fiscal policies } \\
\text { that eventually contribute to a } \\
\text { convergence pattern. }\end{array}$ \\
\hline
\end{tabular}

Launch spreads of UK and US sovereign bonds do vary. The difference seems to be related to the

Controlling for bond and issuer characteristics, bond spreads are expected to be jurisdictions, and differences are expected to disappear through arbitrage Ratha et al. (2018) equal across different legal

Econometric model
EU area 2006-2013 is used as a unique testing ground to control for currency risk, liquidity risk and term structure. perception that U.S. law offers stronger investor protection, and that the investor base for bonds issued under U.S. law is larger than that for bonds issued under U.K. law. The difference in spreads persists in the secondary market even after 180 days, perhaps because of the lack of liquidity, as investors tend to buy and hold these more attractive bonds on a longer-term basis.

Foreign-law bonds indeed carry significantly lower yields in distress periods and this effect rises as the risk of sovereign default increases. The results indicate that in times of crisis governments can borrow at lower rates under foreign law.

First, they present a chronology of legislative acts to incorporate CACs in European sovereign debt contracts alongside landmark lawsuits that have challenged their viability in the context of the Greek government debt
The paper reviews the first

Steffen et al. (2019) CACs for European sovereign debt, focusing on legal and economic dimensions. five years of experience with
Event study find that the introduction of CACs and related lawsuits had limited effects on sovereign bond pricing, both around the time of their announcement as well as in the time since. They conclude that

the gradual and ex ante reform approach was less risky than relying on potential ex post action 
Table A1. Cont.

\begin{tabular}{cc}
\hline Authors & Study \\
\hline & $\begin{array}{c}\text { To assess the determinants of } \\
\text { sovereign bond yield spreads } \\
\text { between 1999 and 2016, } \\
\text { considering a }\end{array}$ \\
(2019) & $\begin{array}{c}\text { non-conventional monetary } \\
\text { policy measures in the Euro } \\
\text { area. }\end{array}$
\end{tabular}

Methodology

Two-step approach: Confirm and estimate the determinants of sovereign bond yield spreads TVC models of each determinant and to analyze the temporal dynamics
The paper shows the comovement of bond yields in the EU before and during the EU sovereign debt crisis is frequency-dependent.
Frequency cohesion and wavelet coherence

Key Findings

Spreads are bid-ask spread, the VIX,

fiscal and rating developments, REER, economic growth, QE measures implemented by ECB Covered Bond Purchase Programme contributed to reduce yield spread. Longer-term refinancing operations contributed to reduce yield spreads in most countries

The comovement is concentrated mainly at low frequencies. The comovement decreased during the crisis but remained high among countries with national currencies. Within the Eurozone a complex heterogeneity in the comovement that spans well beyond the traditional division between the core and the periphery is documented. Overall, the results provide more credibility to the Eurozone fragility hypothesis rather than to those who consider the fundamental factors to be the main driving force of the crisis.

Sovereign risk evaluation for European Union countries. Investigation of the short run and long run relationship between government bond yields and their associated CDS considering the global financial crisis and the European debt crisis. Moreover, exploration of the interactions between changes in sovereign debt ratings and the corresponding credit premium.
Co-integration and Granger causality techniques Event study
The existence of economic integration between credits spreads on government bonds and their underlying CDS resulted in the existence of a long-run equilibrium. Evidence of co-integration between CDS and government bonds was not found for all countries. Most countries support bilateral causality. Findings in the relationship between CDS spreads and credit ratings is negative, but findings have low interpretation power
Overall, the results suggest that sovereign CDS spreads can be considered good forewarning indicators for predicting the evolution of bank CDS spreads. They also find that the effects differ depending on the country and the financial institution. This result suggests that banks are heterogeneously exposed to sovereign credit risk within the same country. One argument relates to the size of these financial institutions and the domestic exposure to sovereign debt. 


\section{Appendix B. CAC Premium}

Table A2. CAC premium for five-year sovereign bonds (Source: Authors).

\begin{tabular}{ccccc}
\hline Country & Yields with CAC & Yields without CAC & CAC Premium & Result \\
\hline DE & -0.234 & -0.216 & -0.027 & negative \\
DE & -0.242 & -0.221 & -0.021 & negative \\
DE & -0.241 & -0.202 & -0.040 & negative \\
BE & -0.101 & -0.111 & 0.010 & positive \\
BE & -0.050 & -0.132 & 0.081 & positive \\
BE & -0.100 & -0.140 & 0.040 & positive \\
BE & -0.067 & -0.085 & 0.017 & positive \\
BE & -0.033 & -0.132 & 0.098 & positive \\
BE & -0.014 & -0.132 & 0.117 & positive \\
FI & -0.116 & -0.155 & 0.040 & positive \\
FR & -0.104 & -0.156 & 0.052 & positive \\
FR & -0.064 & -0.163 & 0.099 & positive \\
FR & -0.018 & -0.163 & 0.145 & positive \\
FR & 0.011 & -0.156 & 0.167 & positive \\
IT & -0.650 & -1.013 & 0.363 & positive \\
IT & 0.342 & 0.257 & 0.085 & positive \\
IT & 0.510 & -1.013 & 1.524 & positive \\
IT & 0.533 & 0.257 & 0.276 & positive \\
IT & 0.598 & 0.257 & 0.341 & positive \\
\hline
\end{tabular}

Table A3. CAC premium for 10-year sovereign bonds (Source: Authors).

\begin{tabular}{cccccc}
\hline Country & Yields with CAC & Yields without CAC & CAC Premium & Result & Rating \\
\hline DE & 0.039 & 0.054 & -0.015 & negative \\
DE & 0.014 & 0.069 & -0.055 & negative & 1 \\
DE & -0.038 & 0.086 & -0.125 & negative & 2 \\
BE & 0.300 & 0.101 & 0.199 & positive & 2 \\
BE & 0.384 & 0.101 & 0.284 & positive & 2 \\
BE & 0.456 & 0.101 & 0.356 & positive & 2 \\
FI & 0.215 & 0.180 & 0.034 & positive & 2 \\
FI & 0.291 & 0.180 & 0.111 & positive & 2 \\
FR & 0.294 & 0.246 & 0.048 & positive & 2 \\
FR & 0.356 & 0.198 & 0.158 & positive & 2 \\
FR & 0.449 & 0.198 & 0.198 & positive & 2 \\
FR & 0.444 & 0.246 & 0.091 & positive & positive \\
NL & 0.242 & 0.151 & 0.150 & 2 \\
NL & 0.301 & 0.151 & & \\
\hline
\end{tabular}


Appendix C. Descriptive Statistics Collective Action Clause

Table A4. Descriptive Statistics 5-year sovereign bond and result (Source: Authors).

\begin{tabular}{|c|c|c|c|c|c|}
\hline \multicolumn{2}{|c|}{ Descriptive Statistic } & \multicolumn{2}{|c|}{ Shapiro-Wilk Test } & \multicolumn{2}{|c|}{ Outliers and Missing Data } \\
\hline Statistic & CAC Premium & Statistic & CAC Premium & Statistic & CAC Premium \\
\hline Mean & 0.177403236 & $\mathrm{~W}$ & 0.535130832 & Mean & 0.17740324 \\
\hline Standard Error & 0.079359996 & $p$-value & $1.04494 \times 10^{-6}$ & Stdev & 0.3459222 \\
\hline Median & 0.08462813 & Alpha & 0.05 & outliers & 0 \\
\hline Standard Deviation & 0.345922204 & normal & no & blank & 0 \\
\hline Sample Variance & 0.119662171 & & & non-num & 0 \\
\hline Kurtosis & 14.29445284 & & & 1 & -0.59003347 \\
\hline Skewness & 3.610926598 & & & 2 & -0.57275542 \\
\hline Range & 1.563312338 & & & 3 & -0.62702932 \\
\hline Maximum & 1.523812211 & & & 4 & -0.48389995 \\
\hline Minimum & -0.03950013 & & & 5 & -0.27774637 \\
\hline Sum & 3.370661486 & & & 6 & -0.39586455 \\
\hline Count & 19 & & & 7 & -0.46248068 \\
\hline AAD & 0.188939157 & & & 8 & -0.22867349 \\
\hline MAD & 0.06720723 & & & 9 & -0.17352987 \\
\hline IQR & 0.127724111 & & & 10 & -0.39837346 \\
\hline & & & & 11 & -0.36213718 \\
\hline & & & & 12 & -0.22568384 \\
\hline & & & & 13 & -0.09270596 \\
\hline & & & & 14 & -0.02969248 \\
\hline & & & & 15 & 0.53716356 \\
\hline & & & & 16 & -0.26819645 \\
\hline & & & & 17 & 3.89223056 \\
\hline & & & & 18 & 0.28535066 \\
\hline & & & & 19 & 0.4740577 \\
\hline
\end{tabular}

Table A5. Descriptive Statistics 10-year sovereign bond and result (Source: Authors).

\begin{tabular}{|c|c|c|c|c|c|}
\hline \multicolumn{2}{|c|}{ Descriptive Statistic } & \multicolumn{2}{|c|}{ Shapiro-Wilk Test } & \multicolumn{2}{|c|}{ Outliers and Missing Data } \\
\hline Statistic & CAC Premium & Statistic & CAC Premium & Statistic & CAC Premium \\
\hline Mean & 0.120367186 & $\mathrm{~W}$ & 0.9911594075 & Mean & 0.12036719 \\
\hline Standard Error & 0.03603245 & $p$-value & 0.999875434 & Stdev & 0.13482108 \\
\hline Median & 0.1307895 & Alpha & 0.05 & outliers & 0 \\
\hline Standard Deviation & 0.134821083 & normal & yes & blank & 0 \\
\hline Sample Variance & 0.018176724 & & & non-num & 0 \\
\hline Kurtosis & -0.46625757 & & & 1 & -1.00290004 \\
\hline Skewness & -0.10794586 & & & 2 & -1.30103565 \\
\hline Range & 0.480248971 & & & 3 & -1.81668143 \\
\hline Maximum & 0.3556892 & & & 4 & 0.58166655 \\
\hline Minimum & -0.12455977 & & & 5 & 1.21165333 \\
\hline Sum & 1.685140604 & & & 6 & 1.74543928 \\
\hline Count & 14 & & & 7 & -0.63818193 \\
\hline $\mathrm{AAD}$ & 0.107560585 & & & 8 & -0.06768441 \\
\hline MAD & 0.089626096 & & & 9 & -0.53676461 \\
\hline \multirow[t]{5}{*}{ IQR } & 0.160845969 & & & 10 & 0.2776236 \\
\hline & & & & 11 & 0.97011915 \\
\hline & & & & 12 & 0.57582103 \\
\hline & & & & 13 & -0.22136884 \\
\hline & & & & 14 & 0.22229397 \\
\hline
\end{tabular}


Table A6. Descriptive Statistics yields on sovereign bond (Source: Authors).

\begin{tabular}{|c|c|c|c|}
\hline \multicolumn{2}{|c|}{ Descriptive Statistic. } & \multicolumn{2}{|c|}{ Shapiro-Wilk Test } \\
\hline Statistic & Yield & Statistic & Yield \\
\hline Mean & 0.205737 & $\mathrm{~W}$ & 0.863732 \\
\hline Standard Error & 0.065275 & $p$-value & $2.86 \times 10^{-7}$ \\
\hline Median & 0.077656 & Alpha & 0.05 \\
\hline Mode & 1.722097 & normal & no \\
\hline Standard Deviation & 0.598254 & & \\
\hline Sample Variance & 0.357908 & & \\
\hline Kurtosis & 2.379935 & & \\
\hline Skewness & 0.952118 & & \\
\hline Range & 3.578876 & & \\
\hline Maximum & 2.035876 & & \\
\hline Minimum & -1.543 & & \\
\hline Sum & 17.28194 & & \\
\hline Count & 84 & & \\
\hline $\mathrm{AAD}$ & 0.404515 & & \\
\hline MAD & 0.228432 & & \\
\hline IQR & 0.470976 & & \\
\hline
\end{tabular}

\section{Appendix D. Two-Stage Linear Regression on Sovereign Bond Yields}

Appendix D.1. Five-Year Sovereign Bonds

Summary statistics and descriptive statistics with yields for five-year sovereign bonds as dependent variable (Source: Authors).

Summary Statistics:

\begin{tabular}{cccccccc}
\hline Variable & Observations & $\begin{array}{c}\text { Obs. with } \\
\text { Missing } \\
\text { Data }\end{array}$ & $\begin{array}{c}\text { Obs. without } \\
\text { Missing Data }\end{array}$ & Minimum & Maximum & $\begin{array}{c}\text { Std. } \\
\text { Deviation }\end{array}$ \\
\hline Yield & 41 & 0 & 41 & -1.543 & 0.598 & -0.099 & 0.375 \\
CAC & 41 & 0 & 41 & 0.000 & 1.000 & 0.561 & 0.502 \\
Ratingdummy1 & 41 & 0 & 41 & 0.000 & 1.000 & 0.220 & 0.419 \\
Ratingdummy2 & 41 & 0 & 41 & 0.000 & 1.000 & 0.537 & 0.505 \\
Ratingdummy3 & 41 & 0 & 41 & 0.000 & 1.000 & 0.244 & 0.435 \\
\hline
\end{tabular}

Summary statistics (instrument variables):

\begin{tabular}{ccccccc}
\hline Variable. & Observations & $\begin{array}{c}\text { Obs. with } \\
\text { Missing } \\
\text { Data }\end{array}$ & $\begin{array}{c}\text { Obs. without } \\
\text { Missing Data }\end{array}$ & Minimum & Maximum & $\begin{array}{c}\text { Std. } \\
\text { Deviation }\end{array}$ \\
\hline $\begin{array}{c}\text { Z date CAC } \\
\text { instr.var. }\end{array}$ & 41 & 0 & 41 & 0.000 & 1.000 & 0.439 \\
\hline $\begin{array}{c}\text { Z date CAC } \\
\text { instr.var. }\end{array}$ & 41 & 0 & 41 & 0.000 & 1.000 & 0.439 \\
\hline $\begin{array}{c}\text { Z date CAC } \\
\text { instr.var. }\end{array}$ & 41 & 0 & 41 & 0.000 & 1.000 & 0.439 \\
\hline $\begin{array}{c}\text { Z date CAC } \\
\text { instr.var. }\end{array}$ & 41 & 0 & 41 & 0.000 & 1.000 & 0.502 \\
\hline
\end{tabular}




\section{Descriptive statistics (Quantitative data):}

\begin{tabular}{cc}
\hline Statistic & Yield \\
\hline Number of observations & 41 \\
Minimum & -1.543 \\
Maximum & 0.598 \\
1st Quartile & -0.216 \\
Median & -0.111 \\
3rd Quartile & -0.018 \\
Mean & -0.099 \\
Variance (n - 1) & 0.140 \\
Standard deviation (n) & 0.370 \\
Standard deviation (n - 1) & 0.375 \\
Standard error of the mean & 0.059
\end{tabular}

Correlation matrix, multicollinearity, regression, and ANOVA with yields for five-year sovereign bonds as dependent variable (Source: Authors).

Multicollinearity statistics:

\begin{tabular}{ccccc}
\hline Statistic & CAC & Ratingdummy1 & Ratingdummy2 & Ratingdummy3 \\
\hline Tolerance & 0.897 & 0.000 & 0.000 & 0.000 \\
VIF & 1.115 & & & \\
\hline
\end{tabular}

\section{Regression of variable yield:}

Goodness of fit statistics:

\begin{tabular}{cc}
\hline Statistic & Output \\
\hline Observations: & 41.000 \\
Sum of weights & 41.000 \\
DF & 39.000 \\
$\mathrm{R}^{2}$ & 0.185 \\
Adjusted R & 0.164 \\
MSE & 0.117 \\
RMSE & 0.343 \\
MAPE & 122.383 \\
DW & 1.826 \\
Cp & 2.000 \\
AIC & -85.882 \\
SBC & -82.455 \\
PC & 0.899 \\
\hline
\end{tabular}

\section{Analysis of variance:}

\begin{tabular}{cccccc}
\hline Source & DF & Sum of Squares & Mean Squares & F & Pr $>$ F \\
\hline Model & 1 & 1.039 & 1.039 & 8.851 & 0.005 \\
Error & 39 & 4.578 & 0.117 & & \\
Corrected total & 40 & 5.617 & & & \\
\hline
\end{tabular}

Computed against model $\mathrm{Y}=$ mean $(\mathrm{Y})$. 


\section{Correlation matrix}

\begin{tabular}{cccccc}
\hline Variables & CAC & Ratingdummy1 & Ratingdummy2 & Ratingdummy3 & Yield \\
\hline CAC & 1.000 & -0.243 & -0.034 & 0.274 & 0.430 \\
Ratingdummy1 & -0.243 & 1.000 & -0.571 & -0.301 & -0.192 \\
Ratingsdummy2 & -0.034 & -0.571 & 1.000 & -0.611 & -0.181 \\
Ratingdummy3 & 0.274 & -0.301 & -0.611 & 1.000 & 0.395 \\
yield & 0.430 & -0.192 & -0.181 & 0.395 & 1.000 \\
\hline
\end{tabular}

Appendix D.2. Ten-Year Sovereign Bonds

Summary statistics and descriptive statistics with yields for ten-year sovereign bonds as dependent variable (Source: Authors).

Summary Statistics:

\begin{tabular}{cccccccc}
\hline Variable & Observations & $\begin{array}{c}\text { Obs. with } \\
\text { Missing } \\
\text { Data }\end{array}$ & $\begin{array}{c}\text { Obs. without } \\
\text { Missing Data }\end{array}$ & Minimum & Maximum & $\begin{array}{c}\text { Std. } \\
\text { Mean }\end{array}$ \\
\hline Yield & 23 & 0 & 23 & -0.042 & 0.456 & 0.208 & 0.155 \\
CAC & 23 & 0 & 23 & 0.000 & 1.000 & 0.609 & 0.499 \\
Ratingdummy & 23 & 0 & 23 & 0.000 & 1.000 & 0.304 & 0.470 \\
\hline
\end{tabular}

Summary statistics (instrument variables):

\begin{tabular}{ccccccc}
\hline Variable & Observations & $\begin{array}{c}\text { Obs. with } \\
\text { Missing } \\
\text { Data }\end{array}$ & $\begin{array}{c}\text { Obs. without } \\
\text { Missing Data }\end{array}$ & Minimum & Maximum & $\begin{array}{c}\text { Std. } \\
\text { Mean }\end{array}$ \\
\hline $\begin{array}{c}\text { Z date CAC } \\
\text { instr.var. }\end{array}$ & 23 & 0 & 23 & 0.000 & 1.000 & 0.391 \\
\hline $\begin{array}{c}\text { Z date CAC } \\
\text { instr.var. }\end{array}$ & 23 & 0 & 23 & 0.000 & 1.000 & 0.391 \\
\hline
\end{tabular}

Descriptive statistics (Quantitative data):

\begin{tabular}{cc}
\hline Statistic & Yield \\
\hline Number of observations & 23 \\
Minimum & -0.042 \\
Maximum & 0.456 \\
1st Quartile & 0.078 \\
Median & 0.215 \\
3rd Quartile & 0.301 \\
Mean & 0.208 \\
Variance (n - 1) & 0.024 \\
Standard deviation (n) & 0.151 \\
Standard deviation (n - 1) & 0.155 \\
Standard error of the mean & 0.032 \\
\hline
\end{tabular}

Correlation matrix, multicollinearity, regression, and ANOVA with yields for five-year sovereign bonds as dependent variable (Source: Authors).

Multicollinearity statistics:

\begin{tabular}{ccc}
\hline Statistic & CAC & Ratingdummy \\
\hline Tolerance & 0.940 & 0.940 \\
VIF & 1.063 & 1.063 \\
\hline
\end{tabular}




\section{Regression of variable yield:}

Goodness of fit statistics:

\begin{tabular}{cc}
\hline Statistic & Yield \\
\hline Observations & 23.000 \\
Sum of weights & 23.000 \\
DF & 21.000 \\
$\mathrm{R}^{2}$ & 0.365 \\
Adjusted $\mathrm{R}^{2}$ & 0.335 \\
MSE & 0.016 \\
RMSE & 0.126 \\
MAPE & 120.311 \\
DW & 0.510 \\
Cp & 2.000 \\
AIC & -93.388 \\
SBC & -91.177 \\
PC & 0.755 \\
\hline
\end{tabular}

Analysis of variance:

\begin{tabular}{cccccc}
\hline Source & DF & Sum of Squares & Mean Squares & F & 12.097 \\
Model & 1 & 0.192 & 0.192 & & 0.002 \\
Error & 21 & 0.333 & 0.016 & & \\
Corrected total & 22 & 0.525 & & & \\
\hline
\end{tabular}

Computed against model $\mathrm{Y}=$ mean $(\mathrm{Y})$.

Correlation matrix:

\begin{tabular}{cccc}
\hline Variables & CAC & Ratingdummy & Yield \\
\hline CAC & 1.000 & -0.244 & 0.605 \\
Ratingdummy & -0.244 & 1.000 & -0.798 \\
yield & 0.605 & -0.798 & 1.000 \\
\hline
\end{tabular}

\section{Appendix E. Multicollinearity and Linear Regression Analysis CAC Premium}

Appendix E.1. Five-Year Sovereign Bonds

Summary statistics, descriptive statistics and multicollinearity CAC premium and correlation matrix (Source: Authors).

Summary Statistics:

\begin{tabular}{cccccccc}
\hline Variable & Observations & $\begin{array}{c}\text { Obs. with } \\
\text { Missing } \\
\text { Data }\end{array}$ & $\begin{array}{c}\text { Obs. without } \\
\text { Missing Data }\end{array}$ & Minimum & Maximum & $\begin{array}{c}\text { Std. } \\
\text { Mean }\end{array}$ \\
\hline CAC & 19 & 0 & 19 & -0.040 & 1.524 & 0.177 & 0.346 \\
Ratingdummy1 & 19 & 0 & 19 & 0.000 & 1.000 & 0.158 & 0.375 \\
Ratingdummy2 & 19 & 0 & 19 & 0.000 & 1.000 & 0.579 \\
Ratingdummy3 & 19 & 0 & 19 & 0.000 & 1.000 & 0.263 \\
\hline
\end{tabular}


Descriptive statistics (Quantitative data):

\begin{tabular}{cc}
\hline Statistic & CAC Premium \\
\hline Number of observations & 19 \\
Minimum & -0.040 \\
Maximum & 1.524 \\
1st Quartile & 0.029 \\
Median & 0.085 \\
3rd Quartile & 0.156 \\
Mean & 0.177 \\
Variance (n - 1) & 0.120 \\
Standard deviation (n) & 0.337 \\
Standard deviation (n - 1) & 0.346 \\
Standard error of the mean & 0.079 \\
\hline
\end{tabular}

Multicollinearity statistics:

\begin{tabular}{ccccc}
\hline Statistic & CAC Premium & Ratingdummy1 & Ratingdummy2 & Ratingdummy3 \\
\hline $\mathrm{R}^{2}$ & 0.378 & 1.000 & 1.000 & 1.000 \\
Tolerance & 0.622 & 0.000 & 0.000 & 0.000 \\
VIF & 1.607 & & & \\
\hline
\end{tabular}

\section{Correlation matrix}

\begin{tabular}{cccccc}
\hline Variables & Result & Ratingdummy1 & Ratingdummy2 & Ratingdummy3 & CAC Premium \\
\hline Result & 1 & -1.000 & 0.508 & 0.259 & 0.265 \\
Ratingdummy1 & -1.000 & 1 & -0.508 & -0.259 & -0.265 \\
Ratingsdummy2 & 0.508 & -0.508 & 1 & -0.701 & -0.343 \\
Ratingdummy3 & 0.259 & -0.259 & -0.701 & 1 & 0.604 \\
CAC premium & 0.265 & -0.265 & -0.343 & 0.604 & 1 \\
\hline
\end{tabular}

Linear regression on CAC premium (Source: Authors).

\section{Regression of variable CAC premium:}

Goodness of fit statistics (CAC premium):

\begin{tabular}{cc}
\hline Statistic & CAC Premium \\
\hline Observations: & 19 \\
Sum of weights & 19 \\
DF & 16 \\
$\mathrm{R}^{2}$ & 0.378 \\
Adjusted R & 0.300 \\
MSE & 0.084 \\
RMSE & 0.289 \\
MAPE & 120.876 \\
DW & 2.834 \\
Cp & 3.000 \\
AIC & -44.383 \\
SBC & -41.550 \\
PC & 0.855 \\
\hline
\end{tabular}


Analysis of variance (CAC premium):

\begin{tabular}{cccccc}
\hline Source & DF & Sum of Squares & Mean Squares & F & 4.859 \\
Model & 2 & 0.814 & 0.407 & 0.022 \\
Error & 16 & 1.340 & 0.084 & \\
Corrected total & 18 & 2.154 & & \\
\hline
\end{tabular}

Computed against model $\mathrm{Y}=$ mean $(\mathrm{Y})$.

Appendix E.2. Ten-Year Sovereign Bonds

Summary statistics, descriptive statistics and multicollinearity CAC premium and correlation matrix (Source: Authors).

Summary Statistics:

\begin{tabular}{cccccccc}
\hline Variable & Observations & $\begin{array}{c}\text { Obs. with } \\
\text { Missing } \\
\text { Data }\end{array}$ & $\begin{array}{c}\text { Obs. without } \\
\text { Missing Data }\end{array}$ & Minimum & Maximum & $\begin{array}{c}\text { Std. } \\
\text { Mean }\end{array}$ \\
\hline $\begin{array}{c}\text { CAC } \\
\text { premium }\end{array}$ & 14 & 0 & 14 & -0.125 & 0.356 & 0.120 & 0.135 \\
$\begin{array}{c}\text { Result } \\
\text { Ratingdummy1 }\end{array}$ & 14 & 0 & 14 & 0.000 & 1.000 & 0.786 & 0.426 \\
Ratingdummy2 & 14 & 0 & 14 & 0.000 & 1.000 & 0.241 & 0.426 \\
\hline
\end{tabular}

Descriptive statistics (Quantitative data):

\begin{tabular}{cc}
\hline Statistic & CAC Premium \\
\hline Number of observations & 14 \\
Minimum & -0.125 \\
Maximum & 0.356 \\
1st Quartile & 0.038 \\
Median & 0.131 \\
3rd Quartile & 0.199 \\
Mean & 0.120 \\
Variance (n - 1) & 0.018 \\
Standard deviation (n) & 0.130 \\
Standard deviation (n - 1) & 0.135 \\
Standard error of the mean & 0.036 \\
\hline
\end{tabular}

Multicollinearity statistics:

\begin{tabular}{cccc}
\hline Statistic & CAC Premium & Ratingdummy1 & Ratingdummy2 \\
\hline$R^{2}$ & 0.554 & 1.000 & 1.000 \\
Tolerance & 0.446 & 0.000 & 0.000 \\
VIF & 2.243 & & \\
\hline
\end{tabular}

\section{Correlation matrix}

\begin{tabular}{ccccc}
\hline Variables & Result & Ratingdummy1 & Ratingdummy2 & CAC Premium \\
\hline Result & 1 & -1.000 & 1.000 & 0.744 \\
Ratingdummy1 & -1.000 & 1 & -1.000 & -0.744 \\
Ratingsdummy2 & 1.000 & -1.000 & 1 & 0.744 \\
CAC premium & 0.744 & -0.744 & 0.744 & 1 \\
\hline
\end{tabular}

Linear regression on CAC premium (Source: Authors). 


\section{Regression of variable CAC premium:}

Goodness of fit statistics (CAC premium):

\begin{tabular}{cc}
\hline Statistic & CAC Premium \\
\hline Observations: & 14 \\
Sum of weights & 14 \\
DF & 12 \\
$\mathrm{R}^{2}$ & 0.554 \\
Adjusted R & 0.517 \\
MSE & 0.009 \\
RMSE & 0.094 \\
MAPE & 97.990 \\
DW & 1.694 \\
Cp & 2.000 \\
AIC & -64.452 \\
SBC & -63.174 \\
PC & 0.595 \\
\hline
\end{tabular}

Analysis of variance (CAC premium):

\begin{tabular}{cccccc}
\hline Source & DF & Sum of Squares & Mean Squares & F & 14.912 \\
Model & 1 & 0.131 & 0.131 & 0.022 \\
Error & 12 & 0.105 & 0.009 & \\
Corrected total & 13 & 0.236 & & \\
\hline
\end{tabular}

Computed against model $\mathrm{Y}=$ mean $(\mathrm{Y})$.

\section{References}

Afonso, António, and João Tovar Jalles. 2019. Quantitative easing and sovereign yield spreads: Euro-area time-varying evidence. Journal of International Financial Markets, Institutions and Money 58: 208-24. [CrossRef]

Agiakloglou, Christos, and Emmanouil Deliagiannakis. 2020. Sovereign risk evaluation for European Union countries. Journal of International Money and Finance 103: 102117. [CrossRef]

Aguiar, Mark, and Manuel Amador. 1938. Sovereign Debt: A Review (NBER Working Papers No. 19388). St. Louis: National Bureau of Economic Research, Inc.

Aizenman, Joshua, Michael Hutchison, and Yothin Jinjarak. 2013. What is the risk of European sovereign debt defaults? Fiscal space, CDS spreads and market pricing of risk. Journal of International Money and Finance 34: 37-59. [CrossRef]

Allegret, Jean-Pierre, Hélène Raymond, and Houda Rharrabti. 2017. The impact of the European sovereign debt crisis on banks stocks. Some evidence of shift contagion in Europe. Journal of Banking and Finance 2017: 24-37. [CrossRef]

Antonakakis, Nikolaos, and Konstantinos Vergos. 2013. Sovereign bond yield spillovers in the Euro zone during the financial and debt crisis. Journal of International Financial Markets, Institutions and Money 26: 258-72. [CrossRef]

Antonakakis, Nikolaos, Christina Christou, Juncal Cunado, and Rangan Gupta. 2017. Convergence patterns in sovereign bond yield spreads: Evidence from the Euro Area. Journal of International Financial Markets, Institutions and Money 49: 129-39. [CrossRef]

Aristei, David, and Duccio Martelli. 2014. Sovereign bond yield spreads and market sentiment and expectations: Empirical evidence from Euro area countries. Journal of Economics and Business 76: 55-84. [CrossRef]

Atkeson, Andrew. 1991. International Lending with moral hazard and risk of repudiation. Econometrica 59: 1069. [CrossRef]

Bardozzetti, Alfredo, and Davide Dottori. 2014. Collective action clauses: How do they affect sovereign bond yields? Journal of International Economics 92: 286-303. [CrossRef]

Bauer, Klaus-Albert. 2013. The Euro's Area Collective Action Clauses-Some Questions and Answers. Institute for Law and Finance Series: Vol. 12. Collective Action Clauses and the Restructuring of Sovereign Debt. de Gruyter. Available online: http://www.degruyter. com/doi/book/10.1515/9783110314526 (accessed on 9 November 2020).

Becker, Torbjörn, Anthony Richards, and Yunyong Thaicharoen. 2003. Bond restructuring and moral hazard: Are collective action clauses costly? Journal of International Economics 61: 127-61. [CrossRef]

Beirne, John, and Marcel Fratzscher. 2013. The pricing of sovereign risk contagion during the European sovereign debt crisis. Journal of International Money and Finance 34: 60-82. [CrossRef]

Bernoth, Kerstin, and Burcu Erdogan. 2012. Sovereign bond yield spreads: A time-varying coefficient approach. Journal of International Money and Finance 31: 639-56. [CrossRef]

Bradley, Michael, and Mitu Gulati. 2013a. Collective Action Clauses for the Eurozone: An empirical analysis. SSRN Electronic Journal. Bradley, Michael, and Mitu Gulati. 2013b. Collective Action Clauses for the Eurozone. Review of Finance 18: 2045-102. [CrossRef] 
Brooks, Chris. 2017. Introductory Econometrics for Finance. Cambridge: Cambridge University Press.

Buchheit, Lee, Mitu Gulati, and Ignacio Tirado. 2013. The problem of holdout creditors in Eurozone sovereign debt restructuring. SSRN Journal.

Bulow, Jeremy, and Kenneth Rogoff. 1989. A constant recontracting model of sovereign debt. Journal of Political Economy 97: 155-78. [CrossRef]

Chamon, Marcos, Julian Schumacher, and Christoph Trebesch. 2018. Foreign-law bonds: Can they reduce sovereign borrowing costs? Journal of International Economics 114: 164-79. [CrossRef]

Chung, Kay, and Michael G. Papaioannou. 2020. Do enhanced Collective Action Clauses affect sovereign borrowing costs? IMF Working Paper 20: 1-44. [CrossRef]

Costantini, Mauro, Matteo Fragetta, and Giovanni Melina. 2014. Determinants of sovereign bond yield spreads in the EMU: An optimal currency area perspective. European Economic Review 70: 337-49. [CrossRef]

Diebold, Francis X., and Kamil Yilmaz. 2012. Better to give than to receive: Predictive directional measurement of volatility spillovers. International Journal of Forecasting 28: 57-66. [CrossRef]

Dixon, Liz, and David Wall. 2000. Collective action problems and collective action clauses. Bank of England Financial Stability Review 6: 142-51.

Dooley, Michael. 2000. Can Output Losses Following International Crises Be Avoided? NBER Working Paper 7531. St. Louis: National Bureau of Economic Research.

Economic and Financial Committee. 2015a. Collective Action Clauses in Euro Area. Available online: https://europa.eu/efc/efc-subcommittee-eu-sovereign-debt-markets/collective-action-clauses-euro-area_en (accessed on 24 May 2015).

Economic and Financial Committee. 2015b. Euro Area Model CAC 2012. Available online: https:/ / europa.eu/efc/efc-sub-committeeeu-sovereign-debt-markets / collective-action-clauses-euro-area/euro-area-model-cac_en (accessed on 24 May 2015).

Eichengreen, Barry. 2003. Restructuring sovereign debt. Journal of Economic Perspectives 17: 75-98.

Eichengreen, Barry, and Ashoka Mody. 2004. Do Collective Action Clauses raise borrowing costs? The Economic Journal 114: 247-64. [CrossRef]

Eichengreen, Barry, and Richard Portes. 1985. Debt and default in the 1930s: Cause and consequences. European Economic Review 30: 641-47.

Europa.eu. 2015. Available online: https://europa.eu/efc/sites/default/files/docs/pages/final_-_cac_public_report.pdf (accessed on 24 May 2015).

Schumacher, Julian, Christoph Tresbech, and Chuck Fang. 2020. Restructuring sovereign bonds: Hold outs, haircuts and effectiveness of CACs. ECB Working Paper No. 2366. Available online: https:/ / ssrn.com/abstract=3519925 (accessed on 24 May 2015).

Gelpern, Anna, and Mitu Gulati. 2013. The wonder-clause. Journal of Comparative Economics 41: 367-85. [CrossRef]

Ghosal, Sayatan, and Kannika Thampanishvong. 2013. Does strengthening Collective Action Clauses (CACs) help? Journal of International Economics 89: 68-78. [CrossRef]

Grossman, Herschel, and John B. Van Huyck. 1985. Sovereign Debt as a Contingent Claim: Excusable Default, Repudiation, and Reputation. St. Louis: National Bureau of Economic Research.

Gugiatti, Michael, and Anthony J. Richards. 2004. The Use of Collective Action Clauses in New York Law Bonds of Sovereign Borrowers, Reserve Bank of Australia. Available online: https:/ /heinonline.org/HOL/LandingPage?handle=hein.journals / geojintl35\&div=33\&id=\&page $=($ accessed on 16 December 2020).

Haldane, Andrew, Adrian Penalver, Victoria Saporta, and Hyun Song Shin. 2005. Analytics of sovereign debt restructuring. Journal of International Economics 65: 315-33. [CrossRef]

Herman, Barry. 2007. Doing the right thing: Dealing with developing country sovereign debt. North Carolina Journal of International Law 32: 5 .

Keddad, Benjamin, and Christophe Schalck. 2020. Evaluating sovereign risk spillovers on domestic banks during the European debt crisis. Economic Modelling 88: 356-75. [CrossRef]

Picarelli Osvaldo, Mattia, Erce Aitor, and Jiang Xu. 2019. The benefits of reducing holdout risk: Evidence from the Euro CAC Experiment, 2013-2018. Capital Markets Law Journal 14: 155-77. [CrossRef]

Pitchford, Rohan, and Mark L. J. Wright. 2010. Holdouts in Sovereign Debt Restructuring: A Theory of Negotiation in a Weak Contractual Environment (NBER Working Papers No. 16632). St. Louis: National Bureau of Economic Research, Inc.

Poghosyan, Trigan. 2012. Long-Run and Short-Run determinants of sovereign bond yields in advanced economies. IMF Working Papers 12: 1. [CrossRef]

Portes, Richard. 2004. Resolution of Sovereign Debt Crises: The New Old Framework. CEPR Working Paper Number 4717. Available online: https:/ / cepr.org/active/publications/discussion_papers/dp.php?dpno=4717 (accessed on 8 September 2015).

Ratha, Dilip, Supriyo De, and Sergio Kurlat. 2018. Does Governing Law Affect Bond Spreads? Emerging Markets Review 6: 60-78. [CrossRef]

Richards, Anthony J., and Michael Gugiatti. 2003a. The use of Collective Action Clauses in New York Law Bonds of sovereign borrowers. SSRN Electronic Journal.

Richards, Anthony J., and Michael Gugiatti. 2003b. Do Collective Action Clauses influence bond yields? New evidence from emerging markets. International Finance 6: 415-47. [CrossRef] 
Ruppert, David. 2004. Statistics and Finance: An Introduction. Springer Texts in Statistics. Springer. Available online: http: / / www.loc.gov/catdir/enhancements/fy0818/2003063814-d.html (accessed on 19 October 2020).

Sabel, David G. 2013. An Introduction to the Euro Area's Model Collective Action Clause. In Institute for Law and Finance Series: Vol. 12. Collective Action Clauses and the Restructuring of Sovereign Debt. Berlin: de Gruyter, pp. 29-44.

Steffen, Christoph Grosse, Sebastian Grund, and Julian Schumacher. 2019. Collective action clauses in the euro area: A law and economic analysis of the first five years. Capital Markets Law Journal 14: 134-54. [CrossRef]

Silvapulle, Param, Jean Pierre Fenech, Alice Thomas, and Rob Brooks. 2016. Determinants of sovereign bond yield spreads and contagion in the peripheral EU countries. Economic Modelling 58: 83-92. [CrossRef]

Stolper, Antonia E., and Sean Dougherty. 2019. Collective Action Clauses: How the Argentina litigation changed the sovereign debt markets. Capital Markets Law Journal 12: 239-52. [CrossRef]

Tsatsaronis, Konstantinos. 1999. The effect of collection action clauses on sovereign bond yields. BIS Quarterly Review: International Financial Banking and Financial Market Development, 22-23.

Vácha, Lukás, Filip Šmolík, and Jaromír Baxa. 2019. Comovement and disintegration of EU sovereign bond markets during the crisis. International Review of Economics \& Finance 64: 541-56. [CrossRef]

Wali Ullah, G. M., and Samiul Parvez Ahmed. 2014. A review of European sovereign debt crisis: Causes and consequences. International Journal of Business and Economics Research 3: 66.

Weidemaier, Mark C., and Mitu Gulati. 2013. A people's history of Collective Action Clauses. Virginia Journal of International Law 54: 52-56. [CrossRef]

Weinschelbaum, Federico, and José Wynne. 2005. Renegotiation, collective action clauses and sovereign debt markets. Journal of International Economics 67: 47-72. [CrossRef]

Werner, Richard A. 2014. Enhanced debt management: Solving the Eurozone crisis by linking debt management with fiscal and monetary policy. Journal of International Money and Finance 49: 443-69. [CrossRef]

Wiesmann, Martin. 2013. CACs and the restructuring of sovereign debt-How would markets react? In Institute for Law and Finance Series: Vol. 12. Collective Action Clauses and the Restructuring of Sovereign Debt. Edited by Klaus Albert Baue, Andreas Cahn and Patrick S. Kenadjian. Berlin: de Gruyter, pp. 1015-112. 